Article

\title{
Bioactivity of Curcumin on the Cytochrome P450 Enzymes of the Steroidogenic Pathway
}

\author{
Patricia Rodríguez Castaño ${ }^{1,2}$, Shaheena Parween ${ }^{1,2}$ and Amit V Pandey $1,2, *$ (D) \\ 1 Pediatric Endocrinology, Diabetology, and Metabolism, University Children's Hospital Bern, \\ 3010 Bern, Switzerland; patricia.rodriguez@dbmr.unibe.ch (P.R.C.); shaheena.parween@dbmr.unibe.ch (S.P.) \\ 2 Department of Biomedical Research, University of Bern, 3010 Bern, Switzerland \\ * Correspondence: amit@pandeylab.org; Tel.: +41-31-632-9637
}

Received: 5 September 2019; Accepted: 16 September 2019; Published: 17 September 2019

\begin{abstract}
Turmeric, a popular ingredient in the cuisine of many Asian countries, comes from the roots of the Curcuma longa and is known for its use in Chinese and Ayurvedic medicine. Turmeric is rich in curcuminoids, including curcumin, demethoxycurcumin, and bisdemethoxycurcumin. Curcuminoids have potent wound healing, anti-inflammatory, and anti-carcinogenic activities. While curcuminoids have been studied for many years, not much is known about their effects on steroid metabolism. Since many anti-cancer drugs target enzymes from the steroidogenic pathway, we tested the effect of curcuminoids on cytochrome P450 CYP17A1, CYP21A2, and CYP19A1 enzyme activities. When using $10 \mu \mathrm{g} / \mathrm{mL}$ of curcuminoids, both the $17 \alpha$-hydroxylase as well as 17,20 lyase activities of CYP17A1 were reduced significantly. On the other hand, only a mild reduction in CYP21A2 activity was observed. Furthermore, CYP19A1 activity was also reduced up to $20 \%$ of control when using $1-100 \mu \mathrm{g} / \mathrm{mL}$ of curcuminoids in a dose-dependent manner. Molecular docking studies confirmed that curcumin could dock onto the active sites of CYP17A1, CYP19A1, as well as CYP21A2. In CYP17A1 and CYP19A1, curcumin docked within $2.5 \AA$ of central heme while in CYP21A2 the distance from heme was $3.4 \AA$, which is still in the same range or lower than distances of bound steroid substrates. These studies suggest that curcuminoids may cause inhibition of steroid metabolism, especially at higher dosages. Also, the recent popularity of turmeric powder as a dilatory supplement needs further evaluation for the effect of curcuminoids on steroid metabolism. The molecular structure of curcuminoids could be modified to generate better lead compounds with inhibitory effects on CYP17A1 and CYP19A1 for potential drugs against prostate cancer and breast cancer.
\end{abstract}

Keywords: curcumin; curcuminoid; diferuloylmethane; E100; CYP19A1; aromatase; estrogen synthase; cytochrome P450

\section{Introduction}

Turmeric, the well-known yellow spice and coloring agent, is found in the cuisine of numerous Asian countries. Turmeric is also recognized for its use in Chinese and Ayurvedic medicine and has been tested for anti-microbial activity as far back as 1949 [1,2]. Turmeric is produced commercially from the dried rhizomes of the plant Curcuma longa, which belongs to the ginger family Zingiberaceae. Curcumin (CI-75300, diferuloylmethane, E100, Natural Yellow 3) is the most abundant of the curcuminoids and enhances wound healing, modulates angiogenesis and the immune system, and has anti-inflammatory, anti-oxidant, anti-infective and anti-cancer activities [3]. Since the discovery of curcumin as a bioactive compound, many biological activities have been described [4]. Curcumin has been shown to modulate molecular signaling pathways, such as the aryl hydrocarbon receptor, the induction of Nuclear factor erythroid 2-related factor 2 (Nrf2) or the inhibition of nuclear factor kappa-light-chain-enhancer of activated $\mathrm{B}$ cells (NF- $\mathrm{kB}$ ), initiating the activation of inflammatory and immunogenic factors. Curcumin 
can also inhibit angiogenesis and induce apoptosis on cancerous cells [5,6]. Curcumin is also involved in the increase of insulin in plasma and the decrease of blood glucose in diabetic patients $[7,8]$.

Several investigators have studied the effect of curcumin in prostate cancer [9]. Chendil et al. showed that curcumin treatment of prostate cancer cell line PC-3 in combination with radiation inhibited tumor necrosis factor (TNF)-alpha-mediated NF- $\kappa B$ activity resulting in B-cell lymphoma 2 (bcl-2) protein downregulation [10]. Curcumin has been shown to downregulate the androgen receptor in prostate cancer cells [11]. Several curcumin analogues have been made and tested in prostate cancer cells and many compounds with cytotoxicity toward prostate cancer cell lines have been identified in these studies [12-18]. Curcumin was also found to exhibit a protective effect against natural and chemical toxicities [19]. Structurally, curcumin has two aryl moieties connected by a seven-carbon chain. By varying the motifs from the primary structure, synthetic molecules can be created and a liposomal curcumin preparation can also be prepared for improved stability and bioavailability [20-22]. A more recent approach to improve bioavailability of curcumin has been to use nano formulations of curcumin [23-25]. Several different nanocurcumin preparations have been made and tested for in vitro as well as in vivo effects and toxicities [26-28]. The nano particle formulations of curcumin have been shown to improve bioavailability and therapeutic potential of curcumin and its analogues and can be considered a medium of choice for delivery of curcuminoids [29-33].

Anti-cancer activity of curcumin was first described by Kuttan et al. in 1985 [34]. Since then, different research groups have been testing curcumin in vitro, and several clinical trials have been carried out to test the biological activities of curcumin preparations [35]. The curcumin molecule itself has poor solubility in water, and therefore, often shows low bioavailability when consumed directly [20,36]. Different methods have been developed to increase curcumin bioavailability, and in it has been shown that combining curcumin with piperine ((2E,4E)-5-(2H-1,3-Benzodioxol-5-yl)-1-(piperidin-1-yl)penta-2,4-dien-1-one), a component of black pepper obtained from Piper nigrum, the bioavailability of curcumin was increased significantly [20,22,37].

Most of the hormonal-dependent cancers, such as breast and prostate cancer, are treated by blocking the synthesis of estrogens and androgens [38], by targeting enzymes from the steroidogenesis pathway (Figure 1). The CYP17A1 enzyme (GeneID: 1586, 10q24.32, GRCh38 chr10:102,830,531-102,837,533, NCBI: NM_000102.4, NP_000093.1, OMIM: 609300) regulates sex steroid biosynthesis in humans through $17 \alpha$-hydroxylase $/ 17,20$ lyase activities and is a target of the anti-prostate cancer drug abiraterone [39-41]. Aromatase (CYP19A1) converts androstenedione and testosterone into estrogens and is a target for the treatment of breast cancer [42-44]. The CYP19A1 protein contains 503 amino acids (NP_000094) and is encoded by the CYP19A1 gene (GeneID:1588, NCBI: NM_000103, 15q21.2, GRCh38 15:51208056-51338597). The cytochrome P450 21-hydroxylase, coded by CYP21A2 (GeneID: 1589, NCBI: NM_000500.9, NP_000491.4, 6p21.33, GRCh38 chr6:32,038,265-32,041,670, OMIM: 613815) is needed for biosynthesis of mineralocorticoids and glucocorticoids. In the adrenals, CYP21A2 converts progesterone into 11-deoxycorticosterone and 17 $\alpha$-hydroxyprogesterone into 11-deoxycortisol [39]. All these cytochromes P450, the CYP17A1, CYP19A1, and CYP21A2 are membrane-bound proteins and belong to the cytochrome P450 protein superfamily. Cytochromes P450 enzymes are involved in the biotransformation of drugs, xenobiotics, and steroid hormones [45]. There are different types of cytochrome P450 proteins in humans. The cytochrome P450 proteins located inside the mitochondrion metabolize steroids and sterols in partnership with ferredoxin and ferredoxin reductase and are called type 1 cytochrome P450 [46]. The majority of cytochrome P450 proteins in humans (50 out of 57) are located in the smooth endoplasmic reticulum and depend on cytochrome P450 oxidoreductase [47] as their redox partner (type 2 cytochrome P450). The microsomal P450 enzymes metabolize drugs, xenobiotics as well as endogenous substrates, including many steroid hormones like pregnenolone, $17 \alpha$-hydroxypregnenolone, dehydroepiandrosterone, testosterone, and androstenedione $[39,47]$. 


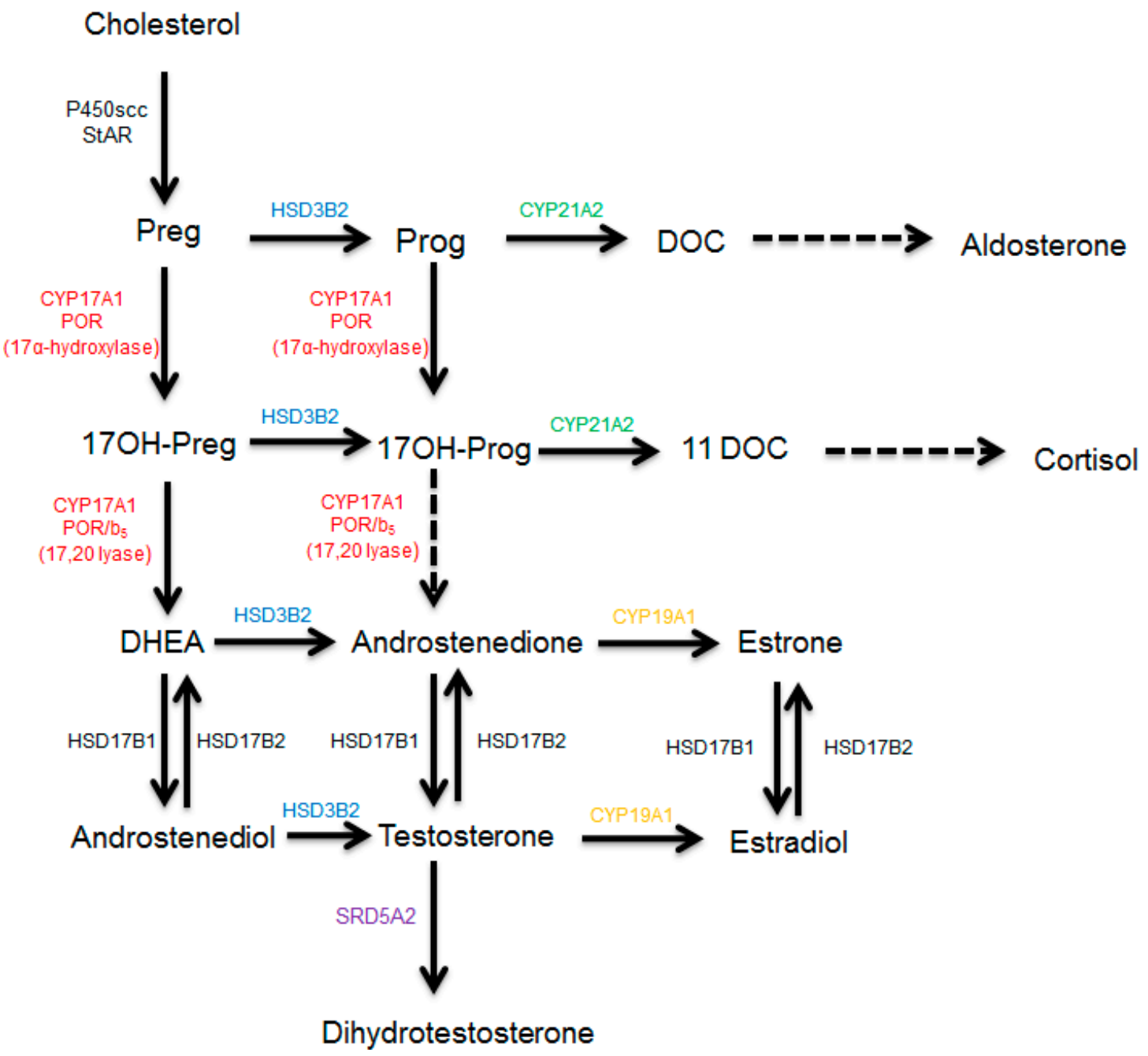

Figure 1. Synthesis of steroid hormones in humans. After entering the mitochondrion, cholesterol is converted into pregnenolone, which is used as a substrate by CYP17A1 in the endoplasmic reticulum to produce sex steroids. First, the cholesterol is converted into pregnenolone by the enzyme CYP11A1 (P450scc) inside the mitochondria. Pregnenolone is converted into progesterone by HSD3B2 and into $17 \mathrm{OH}$-pregnenolone by the $17 \alpha$-hydroxylase activity of CYP17A1. Progesterone is converted into deoxycorticosterone by CYP21A2 and into $17 \mathrm{OH}$-progesterone by the $17 \alpha$-hydroxylase activity of CYP17A1. The 17,20 lyase activity of human CYP17A1 converts $17 \mathrm{OH}$-pregnenolone into DHEA but has poor specificity for $17 \mathrm{OH}$-progesterone as a substrate. The $17 \mathrm{OH}$-progesterone is converted into 11-DOC by the 21-hydroxylase activity of CYP21A2. The CYP19A1 (aromatase) converts androgens into estrogens and uses androstenedione as its major substrate. The $5 \alpha$-reductase, SRD5A2, converts testosterone into dihydrotestosterone. Abbreviations: Preg = pregnenolone, Prog = progesterone, DOC $=$ deoxycorticosterone, $11 \mathrm{DOC}=11$-deoxycortisol, DHEA = dehydroepiandrosterone, HSD3B2 = $3 \beta$-hydroxysteroid dehydrogenase type 2, HSD17B1/2 = 17 $\beta$-hydroxysteroid dehydrogenase type 1/2, SRD5A2 $=5 \alpha$-reductase type 2 .

Curcumin, demethoxycurcumin, and bisdemethoxycurcumin are the most abundant components of turmeric; together, these are called curcuminoids (Figure 2). While activities of curcuminoids have been tested against a wide range of metabolic targets, not much is known about the effect of curcuminoids on the steroid metabolism in humans. Considering the widespread use of turmeric powder, which is rich in curcuminoids, we sought to examine the effects of curcuminoids extracted from C. longa on the metabolism of steroid hormones. Here we report that curcuminoids may inhibit the biosynthesis of steroid hormones. We tested the effect of curcuminoids at different dosages on the activities of steroid-metabolizing enzymes, CYP17A1 and CYP21A2, using adrenal carcinoma 
cell line NCI-H295R and the endoplasmic reticulum from the placental carcinoma cell line JEG3 was used for CYP19A1 activity. Inhibition of CYP17A1 and CYP19A1 activities by curcuminoids indicate similar molecular entities or modified compounds based on core structures of curcuminoids could be explored as potential treatments for prostate cancer by targeting CYP17A1 and for breast cancer by targeting CYP19A1.<smiles>COc1cc(/C=C/C(=O)CC(=O)/C=C/c2ccc(O)c(OC)c2)ccc1O</smiles>

CHEBI:3962 - Curcumin<smiles>COc1cc(/C=C/C(=O)CC(=O)/C=C/c2ccc(Br)cc2)ccc1O</smiles>

CHEBI:65737 - Demethoxycurcumin<smiles>O=C(/C=C/c1ccc(O)cc1)CC(=O)/C=C/c1ccc(O)cc1</smiles>

CHEBI:71045 - Bisdemethoxycurcumin<smiles>COc1cc(/C=C/C(=O)CC(=O)CCc2ccc(O)c(OC)c2)ccc1O</smiles>

CHEBI:67262 - Dihydrocurcumin

\section{Demethoxycurcumin}<smiles>COc1cc(CCC(=O)CC(=O)CCc2ccc(O)c(OC)c2)ccc1O</smiles>

\section{CHEBI:67263 - Tetrahydrocurcumin}

Figure 2. Chemical structure of curcuminoids, and characterization of curcuminoids extracted from turmeric used in this study. The main components of turmeric are curcumin, desmethoxycurcumin, and bis-desmethoxycurcumin. Curcuminoids were obtained from the dried turmeric powder (from Curcuma longa) by solvent extraction using ethanol and purified further by selective extraction and crystallization using hexane and isopropanol as described in the methods section. Curcuminoid composition of our turmeric extract was checked by thin-layer chromatography using chloroform:hexane:methanol (1:1:0.1, v/v/v) as the mobile phase. Curcuminoids in our turmeric extract were identified as curcumin $(69.7 \%)$, bisdemethoxycurcumin $(25.8 \%)$, and demethoxycurcumin $(4.5 \%)$ and curcumin was the major component as has been shown in previous publications describing curcuminoid content of C. longa [48].

\section{Results}

\subsection{Isolation of Curcuminoids from Turmeric Powder and Characterization}

We used dried turmeric powder to obtain the curcuminoid preparation used in our experiments. An initial extraction in ethanol was carried out to dissolve the curcuminoids, and then curcuminoids were separated by filtration. Ethanolic extract was dried under nitrogen and then extracted with hexane to remove bound impurities as curcuminoids are not soluble in hexane. After two rounds of hexane extraction, curcuminoids were crystallized in a 50:50 mix of hexane and propanol and then 
dried. A stock solution of curcuminoids was made in ethanol. For the determination of the nature of curcuminoids present in our preparation, a thin-layer chromatographic separation was carried out as described previously. Our curcuminoid preparation indicated the presence of curcumin as the major curcuminoid (69.7\%) and demethoxycurcumin (4.5\%)/bisdemethoxycurcumin $(25.8 \%)$ were present as minor components (Figure 2), which is similar to previous reports describing curcuminoid separation from the powders of $C$. longa. We performed a UV-Vis spectrum analysis of our curcuminoid preparation and saw an absorption maximum at $427 \mathrm{~nm}$ in ethanol (Figure $3 \mathrm{~A}$ ), which was in agreement with values reported previously $[49,50]$. Further analysis with fluorescence spectroscopy indicated an emission maximum between 532-538 nm (Figure 3B). Using the known molar extinction coefficient values of purified curcumin $\left(\varepsilon=61.864 \mathrm{~cm}^{-1} \mathrm{mM}^{-1}\right)$, we calculated the total amount of curcuminoids present in our preparation and observed that estimated values were in agreement with the experimentally determined results, indicating high purity of our curcuminoid preparation (Table 1).

A

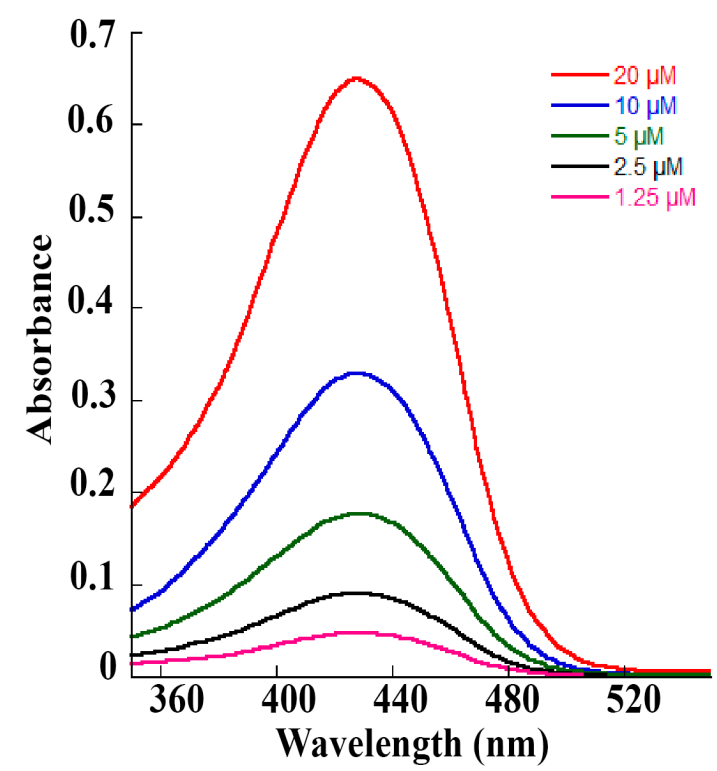

B

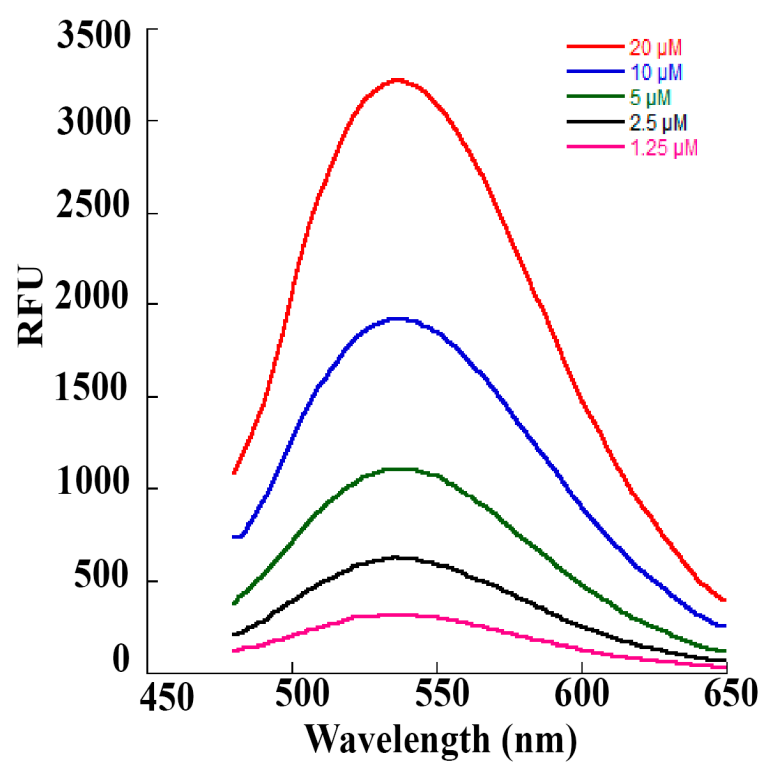

Figure 3. Spectral analysis of curcuminoid preparation used in our studies. (A) UV-Vis spectra of curcuminoid preparations. Curcuminoids were dissolved in ethanol and spectra were recorded on a SpectraMax M2e spectrophotometer between 350-550 $\mathrm{nm}$. Different concentrations of the curcuminoid extract $(1.25-20 \mu \mathrm{M})$ were used for recording the spectra. An absorption maximum of $427 \mathrm{~nm}$ was observed for our curcuminoid preparation. Based on absorption values obtained from our preparation, an estimation of curcuminoid concentration was performed using a millimolar extinction coefficient of $61.864 \mathrm{~cm}^{-1} \mathrm{mM}^{-1}$ for pure curcumin (Table 1). (B) Fluorescence spectra of increasing concentrations $(1.25-20 \mu \mathrm{M})$ of curcuminoid preparation were used in our studies. First, an initial scan of excitation wavelength was performed, then in the emission scans, the excitation wavelength was fixed at $425 \mathrm{~nm}$. A smooth emission maximum between $532-538 \mathrm{~nm}$ was observed for our curcuminoid preparation. 
Table 1. Calculation of curcuminoid concentration based on spectral analysis. Different concentrations of our curcuminoid preparation were analyzed in a SpectraMax M2e spectrophotometer in a volume of $200 \mu \mathrm{L}$ (pathlength $0.56 \mathrm{~cm}$ ). The calculated values were in good agreement with the estimated values, indicating a high degree of purity in our curcuminoid preparation.

\begin{tabular}{ccc}
\hline Estimated Concentration $(\boldsymbol{\mu M})$ & $\mathbf{A}_{\mathbf{4 2 7}}$ Pathlength $\mathbf{0 . 5 6} \mathbf{~ c m}$ & Observed Concentration $(\boldsymbol{\mu M})$ \\
\hline 1.25 & 0.0477 & 1.4 \\
\hline 2.5 & 0.0915 & 2.6 \\
\hline 5 & 0.1787 & 5.2 \\
\hline 10 & 0.3366 & 9.7 \\
\hline 20 & 0.663 & 19.1 \\
\hline
\end{tabular}

\subsection{Toxicity of Curcuminoids on NCI-H295R Cells}

We first determined the toxicity of the curcuminoids towards the steroid metabolizing NCI-H295R adrenal cancer cell line, which was then used in subsequent experiments (Figure 4). A range of curcuminoid concentrations were tested with NCI-H295R cells to determine the maximum concentration of curcuminoid preparation that was not toxic for the cells. We observed that at $50 \mu \mathrm{g} / \mathrm{mL}$ or higher concentrations of curcuminoid preparation, only $25 \%$ of the NCI-H295R cells survived, while at $25 \mu \mathrm{g} / \mathrm{mL}$ or lower concentrations of curcuminoids, most of the cells were found to be viable. We did not observe cell death between $0.78-12.5 \mu \mathrm{g} / \mathrm{mL}$ of curcuminoid preparation, and a standard concentration of $10 \mu \mathrm{g} / \mathrm{mL}$ curcuminoid preparation was used in further experiments. Similarly, the toxicity of curcuminoid preparation was also tested for HEK-293 cells, and no significant toxicity was observed below $6.25 \mu \mathrm{g} / \mathrm{mL}$ or higher concentrations. These results are in agreement with the previously reported toxicity values for curcumin in NIH3T3, H9C2, and HepG2 cells [51]. Human trials using up to $8000 \mathrm{mg}$ of curcumin found no evidence of toxicity [52].

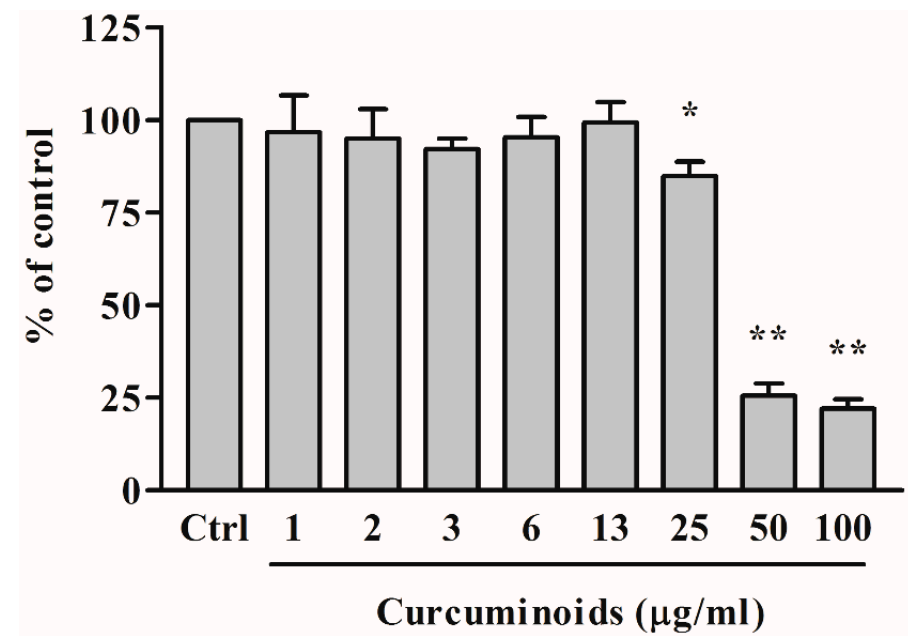

Figure 4. Measurement of cytotoxicity of curcuminoid preparation. Effect of curcuminoids on cytotoxicity and viability of human adrenal NCI-H295R cells was determined using a range of curcuminoid concentrations between $0.78-100 \mu \mathrm{g} / \mathrm{mL}$ over $24 \mathrm{~h}$ as described in methods. The NCI-H295R cells were grown overnight and then treated with varying concentrations of curcuminoids for $24 \mathrm{~h}$. After the incubation with curcuminoids, culture medium was removed, and cell viability was determined by 3-(4,5-dimethylthiazol-2-yl)-2,5-diphenyltetrazolium bromide (MTT) reduction assay. No significant effect on the viability of NCI-H295R cells was observed at $25 \mu \mathrm{g} / \mathrm{mL}$ or lower doses of curcuminoids. In subsequent experiments, the concentration of curcuminoids was kept below $10 \mu \mathrm{g} / \mathrm{mL}$. Data are presented as the mean and standard deviation of three independent replicates. The test for statistical significance was done between each sample with the control (Ctrl) by one-way ANOVA groups marked as * $p<0.05 ; * *<0.001$ confirmed significant changes. 


\subsection{Bioactivity of Curcuminoids on Steroid Biosynthesis}

We tested the bioactivity of our curcuminoid preparation of steroid production by human adrenal NCI-H295R cells [53]. A primary cell line model representing adrenals is not available. The NCI-H295 cells have been shown to express the enzymes involved in the biosynthesis of steroids in human adrenals and therefore, the NCI-H295R cells have been an excellent model to study the molecular mechanisms of steroid regulation and human adrenal steroidogenesis [54,55]. To test the effects of curcuminoids on adrenal steroid production, we treated the NCI-H295R cells with $10 \mu \mathrm{g} / \mathrm{mL}$ of curcuminoid preparation and used pregnenolone as a substrate. We compared the effect of curcuminoids on steroid biosynthesis in NCI-H295R cells with abiraterone, a known inhibitor of CYP17A1 and CYP21A2 activities. The curcuminoids, as well as abiraterone, blocked the production of $17 \alpha$-hydroxypregnenolone and dehydroepiandrosterone (DHEA), indicating inhibition of CYP17A1 activities (Figure 5).

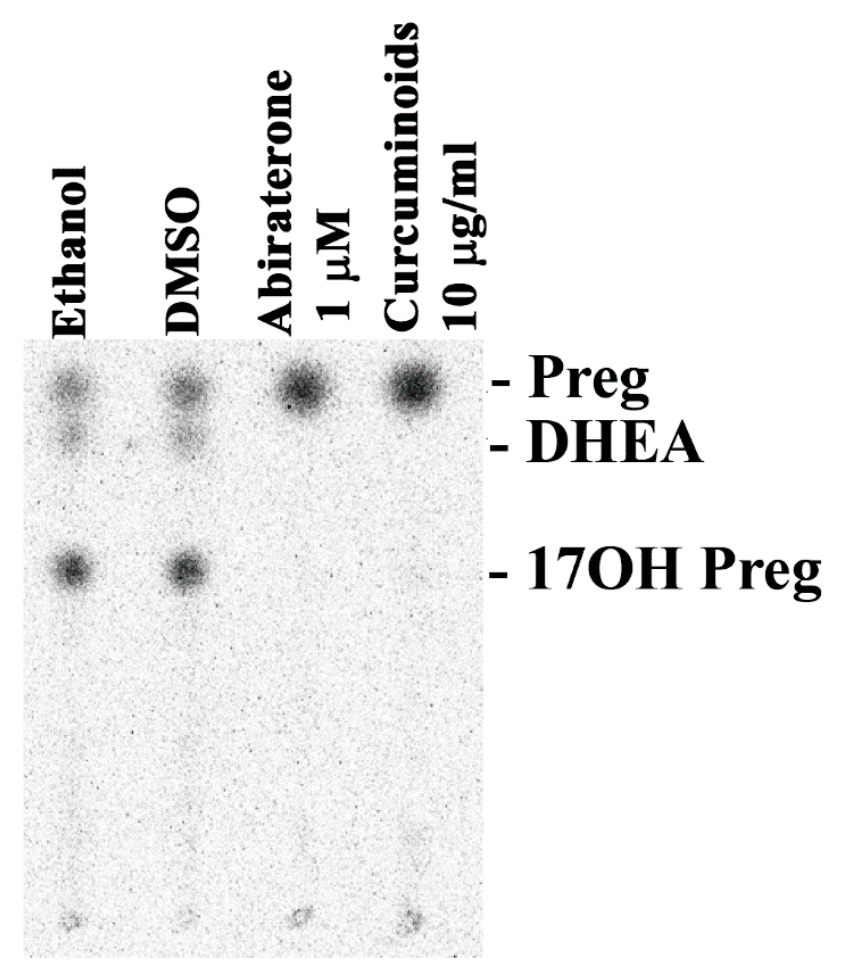

Figure 5. Effect of curcuminoids on steroid production. A representative thin layer chromatogram is shown illustrating the effect on steroid production by the NCI-H295R cells from the curcuminoids extracted from turmeric. Human adrenal NCI-H295R cells were incubated with tritium labeled pregnenolone and then treated with curcuminoids and abiraterone, a known inhibitor of CYP17A1. After incubations, steroids were extracted by organic solvents, dried under nitrogen and separated by thin layer chromatography (TLC). Radioactivity contained in steroids was visualized using autoradiography on a phosphorimager and quantitated by densiometric analysis. Curcuminoids inhibited the formation of $17 \mathrm{OH}$-pregnenolone and DHEA in human adrenal NCI-H295R cells. A block of DHEA production indicates that curcuminoids caused inhibition of both the $17 \alpha$-hydroxylase as well as 17,20 lyase activities of CYP17A1. Ethanol and dimethyl sulfoxide (DMSO) were used as controls at $0.1 \%$ of the total reaction volume.

\subsection{Bioactivity of Curcuminoids on CYP17A1}

After we saw the preliminary results indicating a block of DHEA production by curcuminoids that were similar to inhibition caused by abiraterone, we did further experiments to check the details of steroid biosynthesis inhibition by curcuminoids. We tested the effect of different concentrations of curcuminoids on the $17 \alpha$-hydroxylase and 17,20 lyase activities of CYP17A1 (Figure 6A). We observed 
inhibitory effects of curcuminoids on both the $17 \alpha$-hydroxylase as well as 17,20 lyase activities of CYP17A1 in a dose-dependent manner (Figure 6B,C). Abiraterone, a known inhibitor for CYP17A1, which was used as a control, also inhibited the CYP17A1 activities. Overall, inhibition by curcuminoids of the CYP17A1 17,20 lyase activity seemed stronger compared to the inhibition of the $17 \alpha$-hydroxylase activity (Figure 6C). A stronger inhibition of 17,20 lyase activity may be due to direct competition with 17OH-pregnenolone or blocking the interaction of CYP17A1 with cytochrome $b_{5}$ [56].
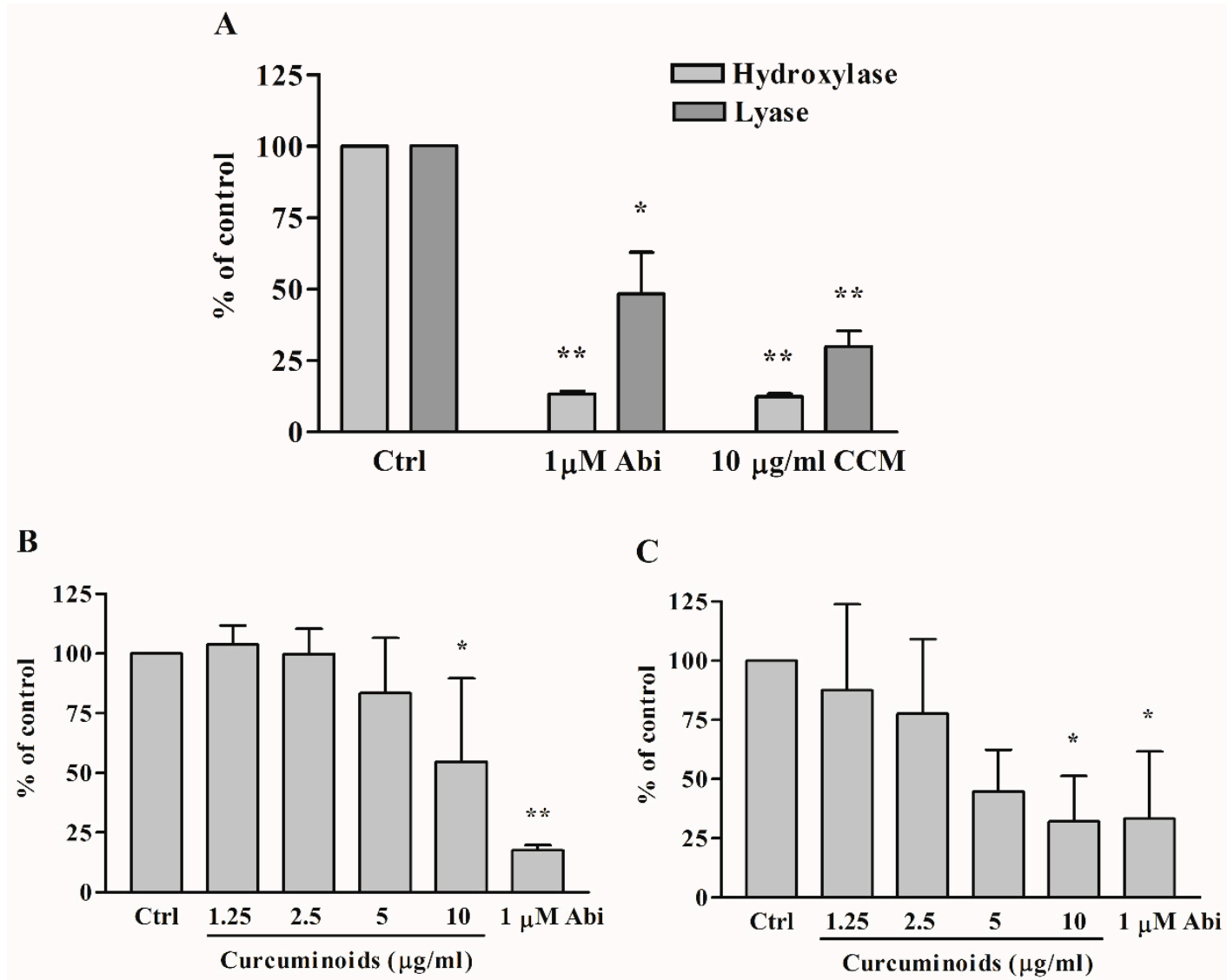

Figure 6. Inhibitory effects of curcuminoids (CCM) on CYP17A1 activities. Abiraterone, a known inhibitor for CYP17A1, was used as a control. Human adrenal NCI-H295R cells were treated with different concentrations of the curcuminoid preparation extracted from turmeric. The CYP17A1 converts pregnenolone into $17 \alpha$-hydroxypregnenolone by its $17 \alpha$-hydroxylase activity, and $17 \alpha$-hydroxypregnenolone is converted into DHEA by the 17,20 lyase activity of CYP17A1. Each experiment was done in triplicate. The final volume of ethanol in experiments was $0.1 \%$, and trilostane (at $1 \mu \mathrm{M}$ concentration) was used to block the activity of HSD3B2, which converts pregnenolone into progesterone. First a pilot experiment was performed to test the effect of curcuminoids (A), and then several different concentrations of curcuminoids were used to determine the inhibition of CYP17A1 activities by curcuminoids (B,C). (A) Inhibition of CYP17A1 17 $\alpha$-hydroxylase activity at a curcuminoid (CCM) concentration of $10 \mu \mathrm{g} / \mathrm{mL}$, and inhibition of CYP17A1 17,20 lyase activity at a curcuminoid concentration of $10 \mu \mathrm{g} / \mathrm{mL}$. (B) Differential inhibition of curcuminoids on CYP17A1 17 $\alpha$-hydroxylase activity. (C) Differential inhibition of curcuminoids on CYP17A1 17,20 lyase activity. Data are presented as the mean and standard deviation (error bars) of three independent replicates with ${ }^{*} p<0.05$; ${ }^{* *} p<0.001$ considered significant. One-way ANOVA was performed between each sample with its own ethanol control to confirm the CYP17A1 inhibition by curcuminoids.

\subsection{Bioactivity of Curcuminoids on CYP21A2}

We used 17-hydroxyprogesterone as a substrate for CYP21A2 activity and monitored the production of 11-deoxycortisol to quantify the effect of curcuminoids. Human adrenal NCI-H295R 
cells do not use 17-hydroxyprogesterone as a substrate of CYP17A1 and therefore, are a good model for assay of CYP21A2 activities using 17-hydroxyprogesterone. We tested the bioactivity of curcuminoids at $5 \mu \mathrm{g} / \mathrm{mL}$ and $10 \mu \mathrm{g} / \mathrm{mL}$ concentrations for effect on CYP21A2 activity (Figure 7). At $10 \mu \mathrm{g} / \mathrm{mL}$ concentration of curcuminoids the reduction in activity of CYP21A2 was not found to be significant compared to the control and was less than the effects observed for inhibition of CYP171 and CYP19A1 activities. The anti-prostate cancer drug abiraterone inhibited CYP21A2 activity as we have shown previously $[40,41]$.

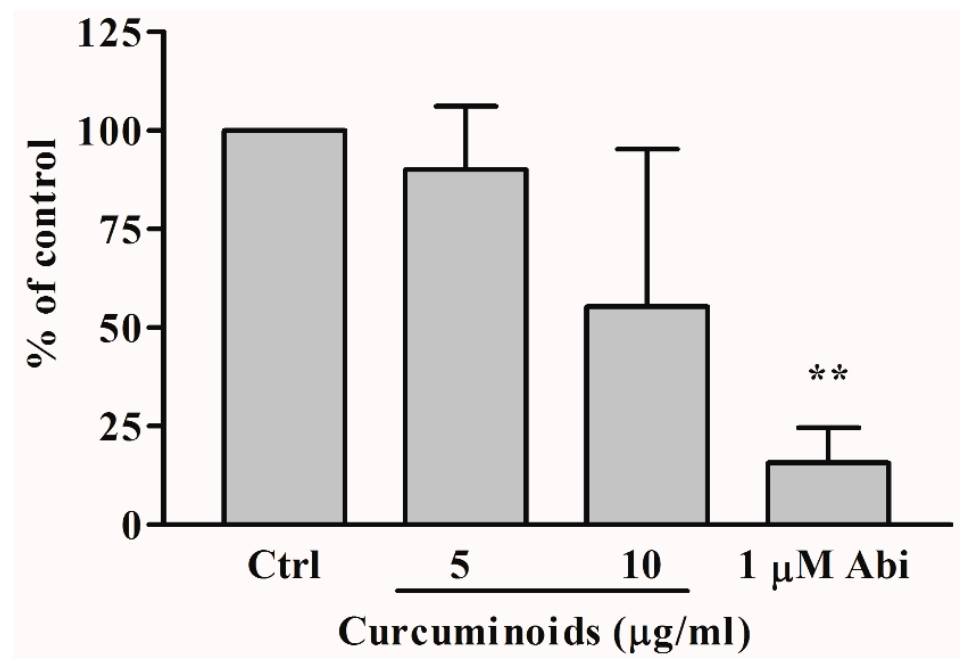

Figure 7. Effect of curcuminoids on CYP21A2 activity. Bioactivity of curcuminoids on CYP21A2 was measured at two different concentrations. Human adrenal NCI-H295R cells were used as a source of CYP21A2 activity. In human adrenals, CYP17A1 does not utilize $17 \alpha$-hydroxyprogesterone as a substrate, and therefore, for the assay of CYP21A2 activity, $17 \alpha$-hydroxyprogesterone was used as a substrate and reaction was monitored by measuring the production of 11-deoxycortisol. NCI-H295R cells were seeded overnight and then incubated with curcuminoids. After the incubations, $\left[{ }^{3} \mathrm{H}\right]-17 \alpha-\mathrm{OH}$ progesterone was added to the medium as the substrate. Following the reactions, steroids were extracted by organic solvents, dried under nitrogen and separated by TLC. Production of 11-deoxycortisol from $17 \alpha-\mathrm{OH}$ progesterone was measured by autoradiographic analysis of steroids on TLC plates as described in methods. The reduction in activity of CYP21A2 observed was not statistically significant at $10 \mu \mathrm{g} / \mathrm{mL}$ of curcuminoids. Ethanol concentration was $0.1 \%$ in the control reaction and abiraterone (Abi), a known inhibitor of CYP21A2, was used as a positive control. Data shown here are from the mean and standard deviation (error bars) of three independent experiments. One-way ANOVA was used as a statistical method to compare each sample with the control giving significant results when ${ }^{* *} p<0.001$.

\subsection{Bioactivity of Curcuminoids on CYP19A1}

To test the effect of curcuminoids on the aromatase activity of CYP19A1, we used androstenedione as substrate and monitored its metabolism by quantifying the release of tritiated water from radiolabeled androstenedione. A preparation of endoplasmic reticulum obtained from the placental JEG3 cells was used for the assay of aromatase enzyme activity. A dose-response effect showing the inhibition of aromatase with the increasing amounts of curcuminoids was seen from 0.78 to $100 \mu \mathrm{g} / \mathrm{mL}$ concentration of curcuminoids (Figure 8). A known inhibitor of CYP19A1, anastrozole was used as a positive control at $100 \mathrm{nM}$ concentration and showed inhibition of CYP19A1 activity as expected. 


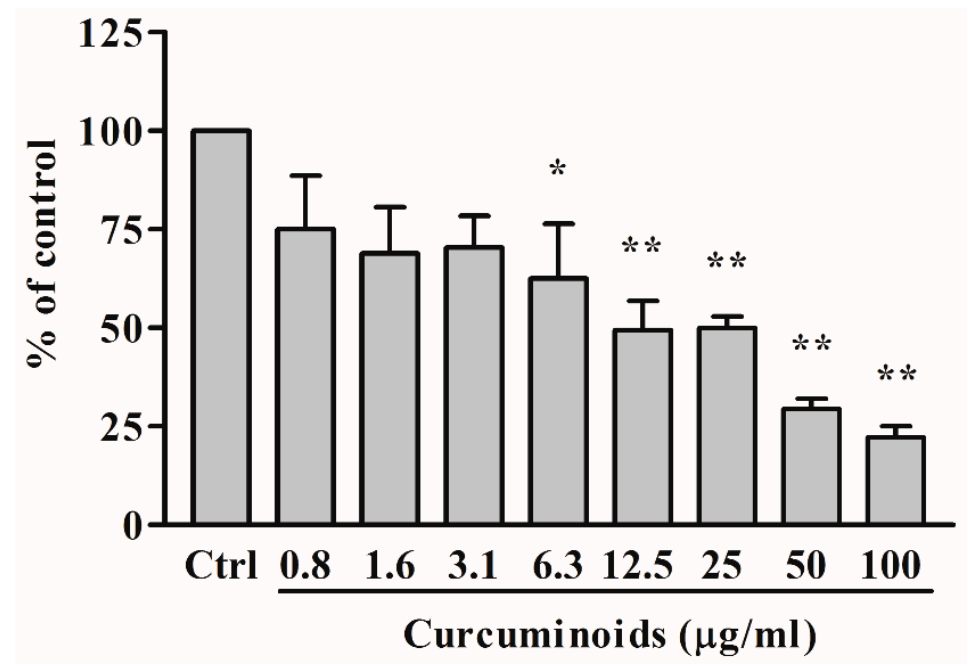

Figure 8. Effect of curcuminoids on CYP19A1 activity. A dose-response profile is shown indicating the inhibition of aromatase by curcuminoids. A preparation of endoplasmic reticulum obtained from JEG3 placental cells was used as a source of aromatase activity, and tritium-labeled androstenedione was used as a substrate. The CYP19A1 reaction was monitored by calculating the amount of tritiated water released by CYP19A1 during the aromatization of androstenedione. A known inhibitor of CYP19A1, anastrozole (100 nM) was used as a positive control. Curcuminoids showed a small effect on CYP19A1 activity $6.25 \mu \mathrm{g} / \mathrm{mL}$ and higher inhibition was observed at 12.5, 25, 50, and $100 \mu \mathrm{g} / \mathrm{mL}$ concentrations of curcuminoids, indicating natural curcuminoids present in C. longa are not potent inhibitors of aromatase activity. Data are presented as the mean and standard deviation of three independent replicates. One-way ANOVA was used as a statistical method to compare each sample with the control (Ctrl) giving significant results at ${ }^{*} p<0.05$ and ${ }^{* *} p<0.001$.

\subsection{Computational Docking of Curcumin into the Human CYP17A1, CYP21A2, and CYP19A1 Crystal Structures}

After observing the inhibitory effects of curcuminoids on CYP17A1, CYP19A1, and CYP21A2, we performed computational docking of curcumin into the protein structures of these cytochromes P450 to understand the molecular nature of inhibition. The molecular structure of curcumin resembles steroid substrates of cytochromes P450 studied in this report, and therefore, we wanted to check whether curcumin fits into the active site of these steroid metabolizing enzymes. Curcumin was docked into the crystal structures of human steroid metabolizing cytochrome P450 CYP17A1, CYP19A1, and CYP21A2 using the docking program Autodock VINA (Figure 9). Superimposition of P450 structures with either their substrates or the curcumin docked into the active site revealed similar binding poses (Figure 9). We observed a close binding pattern from the docking of curcumin into the active sites of CYP17A1 and CYP19A1 crystal structures (heme iron to curcumin distances $<2.5 \AA$ ) (Figure 9). The binding pose of curcumin into CYP21A2 structure was also like its binding into the CYP17A1 and CYP19A1 structures. A comparison of the CYP17A1 and CYP19A1 crystal structures in complex with curcumin and docked curcumin into the crystal structure of CYP21A2 revealed similar binding conformations, but the distance of the curcumin to the central heme iron of CYP21A2 was longer (3.4 Å versus $2.4 \AA$ ) (Figure 9). Binding of curcumin with CYP17A1, CYP19A1, and CYP21A2 shares many similarities with the binding of steroid substrates into the active sites of these cytochrome P450 proteins with many similar active site residues involved in binding. These results indicate that curcumin may act as an active site inhibitor and occupy the same space in cytochrome P450 active sites as used by their steroid substrates. 


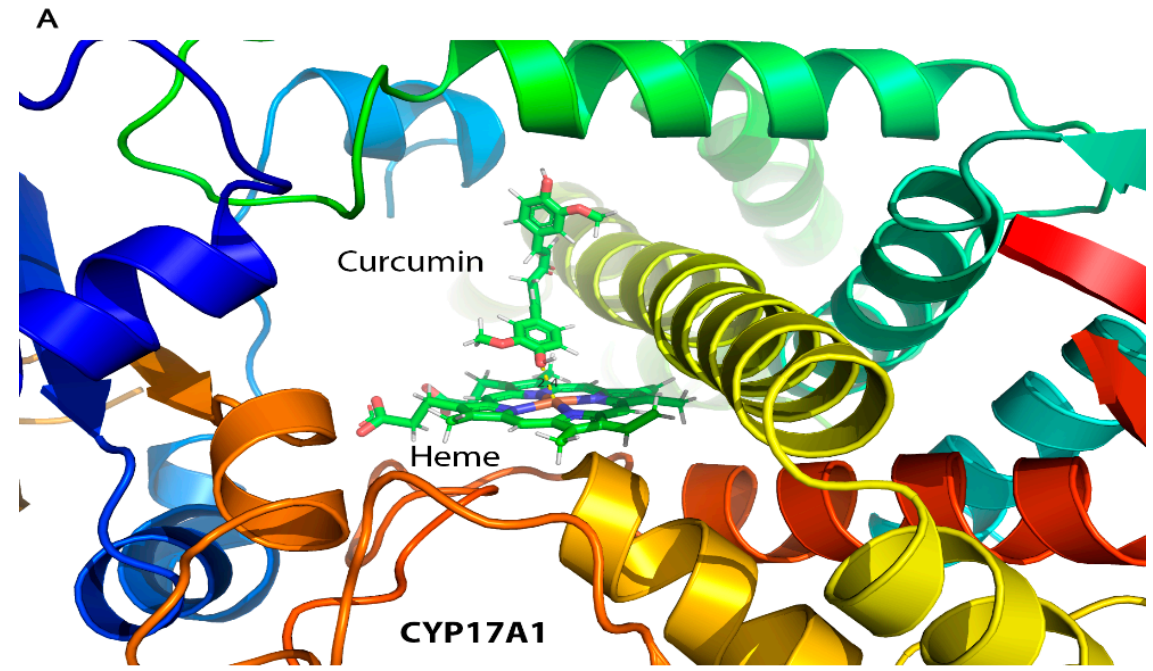

B
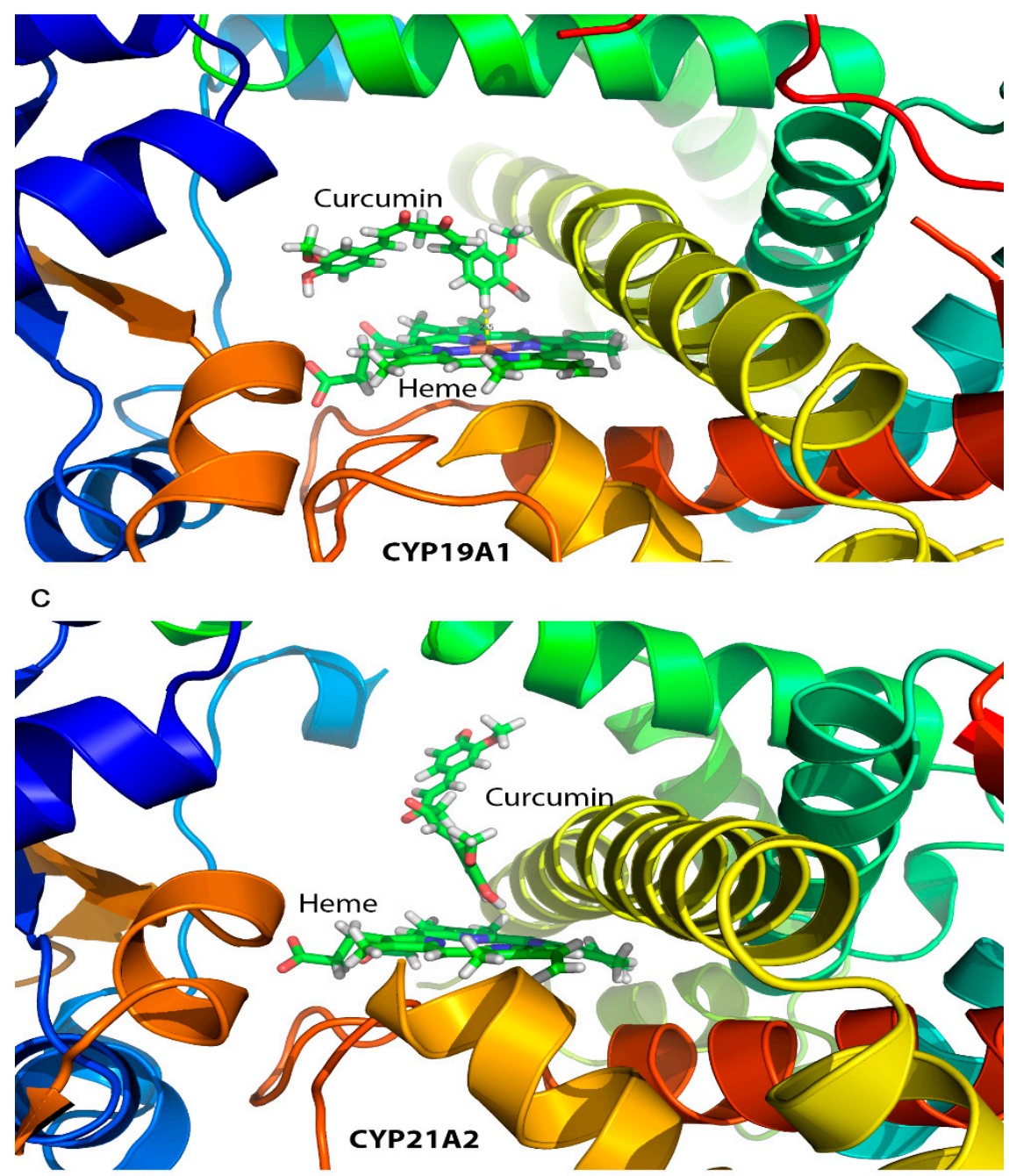

Figure 9. Docking of curcumin into the protein structures of CYP17A1 (A), CYP19A1 (B), and CYP21A2 (C). Published crystal structures of CYP17A1, CYP19A1, and CYP21A2 were used for docking of curcumin by software AUTODOCK-VINA as described in materials and methods. Bound steroid ligands were removed before docking of curcumin into the active site of P450s. The poses in which curcumin docks are similar to steroid substrates of all three P450s, with closer fitting in case of CYP17A1 (A) and CYP19A1 (B) as compared to CYP21A2 (C) (distance from heme $2.5 \AA$ for CYP17A1/CYP19A1 versus $3.4 \AA$ for CYP21A2). 


\section{Discussion}

All steroid hormones are produced from cholesterol [57]. The abnormal production of steroid hormones, for example, the hypercortisolemia seen in Cushing's syndrome, is a life-threatening condition $[58,59]$. The hyperandrogenism is not life-threatening by itself but creates many severe complications during all phases of life. Androgens regulate sexual differentiation in both the female as well as male and disruption of androgen biosynthesis by mutations in steroid metabolizing enzymes, or their redox partners, cause metabolic disorders [60]. Non-tumoral cases of hyperandrogenism include polycystic ovary syndrome (most common metabolic disorder in females), congenital adrenal hyperplasia caused by 21-hydroxylase deficiency, and Cushing's syndrome [61,62]. Overproduction of cortisol and androgens could be therapeutically controlled by inhibitors that block specific steps in steroid biosynthesis.

CYP17A1 catalyzes multiple reactions in the steroid biosynthesis pathway [63-65]. The main activities of CYP17A1 include the $17 \alpha$-hydroxylase activity needed for the biosynthesis of $17 \mathrm{OH}$-pregnenolone (17OH-PREG) and 17OH-progesterone (17OH-PROG), the precursors of cortisol. The CYP17A1 provides qualitative regulation of steroid production in humans by its 17,20 lyase activity that produces dehydroepiandrosterone (DHEA), the precursor of sex steroids. The two distinct enzyme activities of CYP17A1 dictate the nature of steroids synthesized in different types of cells $[39,56]$. Overproduction of androgens by the activation of CYP17A1-17,20 lyase activity has been linked to polycystic ovary syndrome. CYP17A1 is also a metabolic target for chemotherapy of castration-resistant prostate cancer $[40,66]$.

Novel compounds that are safe and non-toxic are needed to target CYP17A1 and CYP19A1 activities to treat metabolic disorders resulting from excess production of androgens or estrogens. Here we have probed the potential of curcuminoids as possible test candidates for synthesizing novel chemicals to target CYP17A1 and CYP21A2. We found a dose-dependent inhibition of both CYP17A1 and CYP19A1 by curcuminoids. In our current study, curcuminoids caused a reduction of CYP21A2 activity. A reduction in CYP21A2 activity was observed at $10 \mu \mathrm{g} / \mathrm{mL}$ concentration of curcuminoids. Based on these results, we can conclude that curcuminoids may cause an intricate pattern of changes in steroid metabolites due to small to moderate inhibition of CYP19A1 and CYP21A2 activities in addition to significant inhibition of $17 \alpha$-hydroxylase as well as 17,20 lyase activity of CYP17A1.

Curcumin has been tested on the five drug-metabolizing enzymes from the cytochrome P450 family, in vivo [67] and in vitro [68,69], showing that CYP1A2, CYP2B6, CYP2C9, CYP2D6, and CYP3A4 can be inhibited by curcuminoids in a dose-dependent matter. Our studies provide an analysis of the inhibitory effects of curcuminoids on CYP17A1 and CYP19A1 activities. These results indicate that steroid production in people with high amounts of curcuma consumption may be affected not only by the inhibition of CYP17A1 activities but also by the inhibition of CYP19A1 and to a smaller extent, the inhibition of CYP21A2 enzyme activity. Also, use of curcuminoids as a common over the counter health supplement requires further caution as inhibition of both CYP17A1 and CYP19A1 activities may potentially result in complications of steroid metabolism in both males and females. Inhibitors of steroidogenesis act on multiple steps in steroid biosynthesis. Many drugs have been approved for use as steroid biosynthesis inhibitors (Ketoconazole, Metyrapone, Etomidate, Mitotane). All these drugs inhibit CYP17A1, CYP11A1, CYP11B1, and CYP19A1 [70]. Also, many other inhibitors which can block androgen biosynthesis in androgen-dependent prostate cancers are being studied [41,71-73]. Curcumin in native forms as well as in nano particle preparations of curcuminoids and their analogues have been tested for their therapeutic role in prostate cancer $[25,74]$. However, the effect of curcuminoids on steroid metabolizing cytochrome P450 enzymes that play a major role in regulation of androgens and estrogens in normal as well as cancerous tissues, has not been studied. Our results describing the inhibitory effect of curcuminoids on CYP17A1 as well as CYP19A1 indicate that some of the effects of curcuminoids seen in studies on prostate cancer and breast cancer cell lines, may be due to inhibition of steroidogenic cytochrome P450 enzymes. 
Stability of curcuminoids has been a major concern for its direct use as it degrades rapidly into trans-6-(4'-hydroxy-3'-methoxy phenyl)-2,4-dioxo-5-hexenal, vanillin, ferulic acid, and feruloyl methane [75]. Some of the curcumin degradation products can have toxic side effects [76]. Bioavailability and stability of curcumin could be improved by the use of sustained-release nanoparticles or liposome preparations [29-33,77]. Several different approaches to prepare nanoparticle formulations of curcumin have been used in recent years and tested in different disease models. A poly(lactic-co-glycolic acid) (PLGA) nanoparticle preparation of curcumin was shown to have good activity in tests on prostate cancer cell lines [25]. An important formulation has been the use of curcumin with piperine, which has been found to enhance the bioavailability as well as effects of curcumin $[78,79]$. A recent study had shown inhibition of SRD5A2 activity by curcumin and some of its synthetic analogues [80]. Synthetic analogues of curcumin have also been shown to have antiparasitic activities against Trypanosoma and Leishmania parasites [81]. A nanocurcumin preparation has been shown to protect against the neurodegenerative effects from cerebral malaria in a mouse model [32]. There is good indication from work on nano particle-based curcumin and its synthetic analogues that bioavailability as well as stability of curcuminoids could be improved. In addition to prostate cancer cell models, curcumin nano particle formulations have been used in many different conditions with improved efficacy and are considered safe for human consumption [82-84]. However, most information about substances like curcumin which are known from traditional medicine is based on herbal formulations and purified active ingredients and their synthetic analogues need validation [85].

\section{Materials and Methods}

\subsection{Materials}

Radiolabeled $\left[{ }^{3} \mathrm{H}\right]$-pregnenolone, [7(N)- $\left.{ }^{3} \mathrm{H}\right]$-pregnenolone (12.6 Ci/mmol), and $\left[{ }^{3} \mathrm{H}\right]$-androstenedione: Andros-4-ene-3, 17-dione, [1 $\left.\beta_{-}{ }^{3} \mathrm{H}(\mathrm{N})\right]-, 250 \mu \mathrm{Ci}(9.25 \mathrm{MBq})$ were purchased from PerkinElmer (Waltham, MA, USA). [ $\left.{ }^{3} \mathrm{H}\right]-17 \alpha-\mathrm{OH}$ progesterone [1, 2, 6, 7-3H] $(60-120 \mathrm{Ci} / \mathrm{mmol} 2.22-4.44 \mathrm{TBq} / \mathrm{mmol})$ was obtained from American Radiolabeled Chemicals Inc. (St. Louis, MO, USA). Silica gel-coated aluminum backed TLC plates were purchased from Macherey-Nagel (Oensingen, Switzerland). The tritium-screens used for the autoradiography were purchased from Fujifilm (Dielsdorf, Switzerland). Turmeric extract capsules (from Curcuma longa) were obtained from the Finest Natural (Item: 943.17, Deerfield, IL, USA). Trilostane was extracted in absolute ethanol (EtOH) from tablets commercially available as Modrenal ${ }^{\circledR}$ (Bioenvision, NY, USA). Abiraterone was purchased from Selleckchem (Houston, TX, USA). Anastrozole was obtained from AstraZeneca (Cambridge, UK).

\subsection{Cell Lines and Culture Media}

Human placental JEG3 cells [86] were purchased from American Type Culture Collection (ATCC) (ATCC: HTB-36 ${ }^{\mathrm{TM}}$ ) and cultured in minimal essential medium (MEM) with Earle's salts (Thermo Fisher Scientific, Waltham, MA, USA) supplemented with 10\% fetal bovine serum, $1 \%$ L-glutamine $(200 \mathrm{mM}$ GIBCO), 1\% penicillin (100 U/ml; GIBCO), and streptomycin $(100 \mu \mathrm{g} / \mathrm{mL}$; (Thermo Fisher Scientific, Waltham, MA, USA)). Human adrenocortical NCI-H295R (NCI-H295R) cells $[53,87,88]$ were purchased from ATCC (ATCC: CRL-2128) and grown in DMEM/Ham's F-12 medium containing L-glutamine and 15 mM HEPES ((Thermo Fisher Scientific, Waltham, MA, USA)) supplemented with 5\% NU-I serum (Becton Dickinson, Franklin Lakes, NJ USA), 0.1\% insulin, transferrin, selenium (100 U/mL; (Thermo Fisher Scientific, Waltham, MA, USA)), 1\% penicillin (100 U/mL; (Thermo Fisher Scientific, Waltham, MA, USA), and streptomycin (100 $\mathrm{\mu g} / \mathrm{mL} ; \mathrm{GIBCO})$ and passage numbers during the experiments remained below 30 according to established protocols $[40,41,55,56,89,90]$. Human embryonic kidney HEK293 cells (ATCC: CRL-1573) [91] were grown in DMEM GlutaMAX TM medium supplemented with $10 \%$ fetal bovine serum (FBS), $1 \%$ antibiotic mix $(100 \times)$, and $1 \mathrm{mM}$ sodium pyruvate. 


\subsection{Curcuminoid Extraction and Analysis}

To obtain a crude turmeric extract, we mixed $20 \mathrm{~g}$ of turmeric in $200 \mathrm{~mL}$ of ethanol and kept it overnight. The ethanol extract was filtered and dried under nitrogen. Pure curcuminoids were obtained by recrystallization using hexane and propanol as described previously. In brief, dried ethanol extract powder was dissolved in hexane and centrifuged at $2000 \times g$ for $15 \mathrm{~min}$, and the supernatant was discarded. The pellet from the hexane extraction was dissolved in a propanol/hexane mixture (50\% propanol $+50 \%$ hexane). The solution was mixed for $90 \mathrm{~min}$ and then stored at $4{ }^{\circ} \mathrm{C}$ overnight for crystallization. The next day, the soluble fraction was removed, and the crystallized curcuminoids were dried under nitrogen. A stock solution of curcuminoid stock was made by mixing $10 \mathrm{mg}$ of the crystallized curcuminoid powder in $1 \mathrm{~mL}$ of $100 \%$ ethanol. The purity of the curcuminoid extract was tested by thin-layer chromatography [92] (Figure 2). Curcuminoid extract was further analyzed by $\mathrm{UV}-\mathrm{Vis}$ and fluorescence spectroscopy to compare the spectral properties of our preparation with previous extraction procedures.

The absorption spectra of curcumin in ethanol were collected using a microplate reader (Spectramax M2e, Molecular Devices, Sunnyvale, CA, USA). In brief, different concentrations of curcumin $(1.25-20 \mu \mathrm{M})$ in ethanol were scanned within the wavelength range of $350-550 \mathrm{~nm}$ at $1 \mathrm{~nm}$ intervals in a total volume of $200 \mu \mathrm{L}$. All UV-Vis measurements were performed at $25{ }^{\circ} \mathrm{C}$ and corrected for the solvent medium (ethanol). Similarly, the fluorescence spectra of varying concentrations of curcuminoids were also recorded at $25^{\circ} \mathrm{C}$ on a microplate spectrofluorometer system (Spectramax M2e, Molecular Devices, Sunnyvale, CA). Ethanol solutions of curcuminoids at 1.25, 2.5, 5, 10, and $20 \mu \mathrm{M}$ concentrations in a volume of $100 \mu \mathrm{L}$ were scanned at $2 \mathrm{~nm}$ intervals. The emission spectra were measured with an excitation wavelength set at $425 \mathrm{~nm}$, and emission was scanned between $480-650 \mathrm{~nm}$.

\subsection{Cell Viability Assay Using 3-(4,5-Dimethylthiazol-2-yl)-2,5-Diphenyltetrazolium Bromide (MTT)}

Human adrenal NCI-H295R cells were seeded in 96-well culture plates at a density of $3 \times 10^{5}$ cells per well and grown overnight at $37{ }^{\circ} \mathrm{C}$ under $5 \% \mathrm{CO}_{2}$, and $90 \%$ humidity. After $24 \mathrm{~h}$, the medium was changed, and serial dilutions of curcuminoids were added to the medium and incubation of cells was continued for another $24 \mathrm{~h}$. After the incubation of cells with curcuminoids, $20 \mu \mathrm{L}$ of MTT reagent $(5 \mathrm{mg} / \mathrm{mL}$ in PBS) was added into each well, and the incubation was continued for another $4 \mathrm{~h}$. After the incubation with MTT reagent, culture medium was removed and $200 \mu \mathrm{L}$ of DMSO was added in each well, and the plate was incubated for $20 \mathrm{~min}$ in the dark. The absorbance in individual wells was then measured at $570 \mathrm{~nm}$, and calculations of cell viability were performed based on residual MTT reduction activity of cells compared to controls without curcuminoids. As another control, the toxicity of curcuminoids on human HEK-293 cells was also tested under similar conditions using the methods described for NCI-H295R cells.

\subsection{Assay of CYP17A1 and CYP21A2 Activities}

Human adrenal NCI-H295R cells were seeded in 6-well tissue culture plates at a density of $1 \times 10^{6}$ cells per well. Steroid metabolism by NCI-H295R cells has been studied in our laboratory for many years and culture conditions and passage numbers (kept below 30) adhered to previously established protocols $[40,41,55,56,89,90]$. After overnight incubation, medium was changed, and different concentrations of curcuminoids were added to the incumation medium and incubation was continued for $24 \mathrm{~h}$. A known inhibitor of CYP17A1 and CYP21A2, abiraterone $(1 \mu \mathrm{M})$, was used as a control for both assays. NCI-H295R cells were treated with trilostane $(1 \mu \mathrm{M})$, an inhibitor of HSD3B2, 90 min before the addition of radiolabeled substrates. For CYP17A1 activity assays, $100,000 \mathrm{cpm} / \mathrm{well}$ of $\left[{ }^{3} \mathrm{H}\right]$-pregnenolone was added to each well. For the determination of CYP21A2 activity, $\left[{ }^{3} \mathrm{H}\right]-17 \alpha-\mathrm{OH}$ progesterone $(\sim 50,000 \mathrm{cpm} /$ well $)$ was used as a substrate. After incubations with radiolabeled substrates, medium from each well was collected, and steroids were extracted in ethyl acetate:isooctane (1:1). Extracted steroids were concentrated under nitrogen and dissolved in $20 \mu \mathrm{L}$ of trichloromethane 
for separation by thin-layer chromatography on silica gel thin layer chromatography (TLC) plates (Macherey-Nagel, Oensingen, Switzerland). Radiolabeled steroids were quantified by autoradiography on a Fuji FLA-7000 PhosphorImager (Fujifilm, Dielsdorf, Switzerland). Quantification of steroids was done using MultiGauge software (Fujifilm, Dielsdorf, Switzerland).

\subsection{Preparation of Microsomes from JEG3 Cells}

JEG3 cells were collected near confluency and washed with cold PBS. The cell suspension was then centrifuged at $1500 \times g$ for 5 min to pellet the cells. Afterward, the cell pellet was suspended in $100 \mathrm{mM} \mathrm{Na}_{3} \mathrm{PO}_{4}$ (pH 7.4) containing $150 \mathrm{mM} \mathrm{KCl}$, and the cells were lysed by sonication. Unbroken cells and mitochondria were pelleted by centrifugation at $14,000 \times \mathrm{g}$ for $15 \mathrm{~min}$ at $4{ }^{\circ} \mathrm{C}$. Microsomes containing endoplasmic reticulum were collected by ultracentrifugation at $100,000 \times g$ for $90 \mathrm{~min}$ at $4{ }^{\circ} \mathrm{C}$ and resuspended in $50 \mathrm{mM} \mathrm{K}_{3} \mathrm{PO}_{4}$ (pH 7.4) containing $20 \%$ glycerol [56]. The protein content of microsomes was measured by the BioRad Protein Assay Kit (BioRad, Hercules, CA, USA).

\subsection{Assay of CYP19A1 Activity}

The aromatase activity of CYP19A1 was measured by calculating the release of tritiated water from the substrate during aromatization. Assays of aromatase activity were carried out using $40 \mu \mathrm{g}$ of microsomes from JEG3 cells in $100 \mathrm{mM}$ potassium phosphate buffer ( $\mathrm{pH}$ 7.4) containing $100 \mathrm{mM} \mathrm{NaCl}$ in a final volume of $200 \mu \mathrm{L}$. Different concentrations of curcuminoids were added to reaction mixtures, and ethanol was used as the control. A known inhibitor of CYP19A1, anastrozole was included in some reactions as a positive control. Assays were performed using $50 \mathrm{nM}$ androstenedione as a substrate and contained $\sim 20,000 \mathrm{cpm}$ of $\left[{ }^{3} \mathrm{H}\right]$-androstenedione as a radioactive tracer. The aromatase reaction was initiated by the addition of reduced nicotinamide adenine dinucleotide phosphate (NADPH) to $1 \mathrm{mM}$ final concentration and incubations were done at $37^{\circ} \mathrm{C}$ with constant shaking for $1 \mathrm{~h}$. Afterward, $800 \mu \mathrm{L}$ of a solution containing $5 \%$ charcoal with $0.5 \%$ dextran was added to each reaction mixture and mixed by vortexing followed by centrifugation at $15,000 \times g$ for $10 \mathrm{~min}$. From each reaction, $500 \mu \mathrm{L}$ aliquots were taken for the measurement of radioactivity by scintillation counting using the Rotiszint Universal Cocktail (Carl Roth $\mathrm{GmbH}$, Karlsruhe, Germany), and aromatase activity was calculated as described previously $[93,94]$.

\subsection{Docking of Curcumin into CYP17A1, CYP19A1, and CYP21A2 Protein Structures}

The published 3D structures of human CYP17A1, CYP19A1, and CYP21A2 were obtained from the protein data bank (PDB) database. We made in-silico calculations and structure analysis with YASARA [95]. For docking experiments, X-ray crystal structures of human of CYP17A1 (PDB\# 3RUK), CYP19A1 (PDB\# 3EQM), and CYP21A2 (PDB \# 4Y8W), were used [96-98]. Missing hydrogen atoms in the structures were added with YASARA [95], which was also used for all other calculations. The resulting minimum energy structures were used for AutoDock VINA [99] to perform docking experiments with curcumin (orthorhombic docking was grid established around the central heme molecule). The final poses of curcumin were selected based on their docking location and scores, and resemblance to the co-crystallized ligands in the P450 structures. Structure models were drawn with Pymol (Schrödinger, New York, NY, USA)

\subsection{Statistical Analysis}

For the statistical analysis, Microsoft Excel and GraphPad Prism (Graph Pad Software, Inc. San Diego, CA, USA) were used. Data are presented as the mean and standard deviation of 3 independent replicates. One-way ANOVA was used to calculate the differences between the samples with the corresponding controls. Significance cutoffs for experiments was set at ${ }^{*}<0.05$ and ${ }^{* *} p<0.001$. 


\section{Conclusions}

Computational docking from our experiments showed that curcumin could bind into the active sites of steroid metabolizing P450s. The inhibition of CYP17A1 and CYP19A1 by curcuminoids provides a template for structure modification to produce effective and safe compounds that can target prostate cancer as well as breast cancer. Curcumin-based compounds can be further optimized for delivery as nano formulations, which have been tried in laboratory animals $[37,100,101]$ as well as in human trials and shown to be safe $[29,82]$. Only a minor effect on CYP21A2 activity by curcuminoids compared to inhibition of CYP17A1 (50\% inhibition of 17,20 lyase activity at $5 \mu \mathrm{g} / \mathrm{ml}$ compared to no significant effect on CYP21A2 activity at the same concentration) was observed. This suggests that compounds based on curcuminoids may be better and safer inhibitors for use in hyperandrogenic states like polycystic ovary syndrome, especially in children and young adults, and avoid the toxic effects of abiraterone which severely inhibits CYP21A2 activity [40,41].

Author Contributions: Conceptualization, A.V.P.; formal analysis, P.R.C. and A.V.P.; funding acquisition, A.V.P.; investigation, P.R.C. and S.P.; methodology, P.R.C. and S.P.; project administration, A.V.P.; supervision, A.V.P.; writing-original draft, A.V.P.; writing—review and editing, A.V.P.

Funding: This research received no external funding.

Conflicts of Interest: The authors declare no conflicts of interest.

\section{References}

1. Schraufstatter, E.; Bernt, H. Antibacterial action of curcumin and related compounds. Nature 1949, $164,456$. [CrossRef] [PubMed]

2. Ammon, H.P.; Wahl, M.A. Pharmacology of Curcuma longa. Planta Med. 1991, 57, 1-7. [CrossRef] [PubMed]

3. Parsai, S.; Keck, R.; Skrzypczak-Jankun, E.; Jankun, J. Analysis of the anticancer activity of curcuminoids, thiotryptophan and 4-phenoxyphenol derivatives. Oncol. Lett. 2014, 7, 17-22. [CrossRef]

4. Priyadarsini, K.I. Photophysics, photochemistry and photobiology of curcumin: Studies from organic solutions, bio-mimetics and living cells. J. Photochem. Photobiol. C Photochem. Rev. 2009, 10, 81-95. [CrossRef]

5. Kumar, G.; Mittal, S.; Sak, K.; Tuli, H.S. Molecular mechanisms underlying chemopreventive potential of curcumin: Current challenges and future perspectives. Life Sci. 2016, 148, 313-328. [CrossRef] [PubMed]

6. Jagetia, G.C.; Aggarwal, B.B. Spicing up of the immune system by curcumin. J. Clin. Immunol. 2007, 27, 19-35. [CrossRef]

7. Karlowicz-Bodalska, K.; Han, S.; Freier, J.; Smolenski, M.; Bodalska, A. Curcuma Longa as Medicinal Herb in the Treatment of Diabetic Complications. Acta Pol. Pharm. 2017, 74, 605-610.

8. Khaliq, T.; Sarfraz, M.; Ashraf, M.A. Recent Progress for the Utilization of Curcuma longa, Piper nigrum and Phoenix dactylifera Seeds against Type 2 Diabetes. West Indian Med. J. 2015, 64, 527-532.

9. Guo, W.; Wu, X.; Li, Y.; Gao, J.; Wang, F.; Jin, Y.; Chong, T.; Malhotra, A. Evaluation of biophysical as well as biochemical potential of curcumin and resveratrol during prostate cancer. J. Drug Target. 2019, 1-21. [CrossRef]

10. Chendil, D.; Ranga, R.S.; Meigooni, D.; Sathishkumar, S.; Ahmed, M.M. Curcumin confers radiosensitizing effect in prostate cancer cell line PC-3. Oncogene 2004, 23, 1599-1607. [CrossRef]

11. Nakamura, K.; Yasunaga, Y.; Segawa, T.; Ko, D.; Moul, J.W.; Srivastava, S.; Rhim, J.S. Curcumin down-regulates AR gene expression and activation in prostate cancer cell lines. Int. J. Oncol. 2002, 21, 825-830. [CrossRef] [PubMed]

12. Ohtsu, H.; Xiao, Z.; Ishida, J.; Nagai, M.; Wang, H.K.; Itokawa, H.; Su, C.Y.; Shih, C.; Chiang, T.; Chang, E.; et al. Antitumor agents. 217. Curcumin analogues as novel androgen receptor antagonists with potential as anti-prostate cancer agents. J. Med. Chem. 2002, 45, 5037-5042. [CrossRef]

13. Chen, S.; Nimick, M.; Cridge, A.G.; Hawkins, B.C.; Rosengren, R.J. Anticancer potential of novel curcumin analogs towards castrate-resistant prostate cancer. Int. J. Oncol. 2018, 52, 579-588. [CrossRef] [PubMed]

14. Zhou, D.Y.; Zhao, S.Q.; Du, Z.Y.; Zheng, X.I.; Zhang, K. Pyridine analogues of curcumin exhibit high activity for inhibiting CWR-22Rv1 human prostate cancer cell growth and androgen receptor activation. Oncol. Lett. 2016, 11, 4160-4166. [CrossRef] [PubMed] 
15. Sharma, V.; Kumar, L.; Mohanty, S.K.; Maikhuri, J.P.; Rajender, S.; Gupta, G. Sensitization of androgen refractory prostate cancer cells to anti-androgens through re-expression of epigenetically repressed androgen receptor - Synergistic action of quercetin and curcumin. Mol. Cell. Endocrinol. 2016, 431, 12-23. [CrossRef]

16. Mandalapu, D.; Saini, K.S.; Gupta, S.; Sharma, V.; Malik, M.Y.; Chaturvedi, S.; Bala, V.; Thakur, S.; Maikhuri, J.P.; Wahajuddin, M.; et al. Synthesis and biological evaluation of some novel triazole hybrids of curcumin mimics and their selective anticancer activity against breast and prostate cancer cell lines. Bioorg. Med. Chem. Lett. 2016, 26, 4223-4232. [CrossRef] [PubMed]

17. Jordan, B.C.; Mock, C.D.; Thilagavathi, R.; Selvam, C. Molecular mechanisms of curcumin and its semisynthetic analogues in prostate cancer prevention and treatment. Life Sci. 2016, 152, 135-144. [CrossRef] [PubMed]

18. Chen, Q.H. Curcumin-based anti-prostate cancer agents. Anticancer Agents Med. Chem. 2015, 15, 138-156. [CrossRef]

19. Hosseini, A.; Hosseinzadeh, H. Antidotal or protective effects of Curcuma longa (turmeric) and its active ingredient, curcumin, against natural and chemical toxicities: A review. Biomed. Pharm. Biomed. Pharm. 2018, 99, 411-421. [CrossRef]

20. Anand, P.; Kunnumakkara, A.B.; Newman, R.A.; Aggarwal, B.B. Bioavailability of curcumin: Problems and promises. Mol. Pharm. 2007, 4, 807-818. [CrossRef]

21. Anand, P.; Thomas, S.G.; Kunnumakkara, B.A.; Sundaram, C.; Harikumar, K.B.; Sung, B.; Tharakan, S.T.; Misra, K.; Priyadarsini, I.K.; Rajasekharan, K.N.; et al. Biological activities of curcumin and its analogues (Congeners) made by man and Mother Nature. Biochem. Pharm. 2008, 76, 1590-1611. [CrossRef] [PubMed]

22. Mach, C.M.; Chen, J.H.; Mosley, S.A.; Kurzrock, R.; Smith, J.A. Evaluation of liposomal curcumin cytochrome p450 metabolism. Anticancer Res. 2010, 30, 811-814. [PubMed]

23. Thangapazham, R.L.; Puri, A.; Tele, S.; Blumenthal, R.; Maheshwari, R.K. Evaluation of a nanotechnology-based carrier for delivery of curcumin in prostate cancer cells. Int. J. Oncol. 2008, 32, 1119-1123. [CrossRef] [PubMed]

24. Yallapu, M.M.; Dobberpuhl, M.R.; Maher, D.M.; Jaggi, M.; Chauhan, S.C. Design of curcumin loaded cellulose nanoparticles for prostate cancer. Curr. Drug Metab. 2012, 13, 120-128. [CrossRef] [PubMed]

25. Yallapu, M.M.; Khan, S.; Maher, D.M.; Ebeling, M.C.; Sundram, V.; Chauhan, N.; Ganju, A.; Balakrishna, S.; Gupta, B.K.; Zafar, N.; et al. Anti-cancer activity of curcumin loaded nanoparticles in prostate cancer. Biomaterials 2014, 35, 8635-8648. [CrossRef] [PubMed]

26. Francis, A.P.; Ganapathy, S.; Palla, V.R.; Murthy, P.B.; Devasena, T. Future of nano bisdemethoxy curcumin analog: Guaranteeing safer intravenous delivery. Environ. Toxicol. Pharm. 2015, 39, 467-474. [CrossRef]

27. Chang, C.Z.; Wu, S.C.; Lin, C.L.; Kwan, A.L. Curcumin, encapsulated in nano-sized PLGA, down-regulates nuclear factor kappaB (p65) and subarachnoid hemorrhage induced early brain injury in a rat model. Brain Res. 2015, 1608, 215-224. [CrossRef]

28. Young, N.A.; Bruss, M.S.; Gardner, M.; Willis, W.L.; Mo, X.; Valiente, G.R.; Cao, Y.; Liu, Z.; Jarjour, W.N.; $\mathrm{Wu}, \mathrm{L}$.C. Oral administration of nano-emulsion curcumin in mice suppresses inflammatory-induced NFkappaB signaling and macrophage migration. PLoS ONE 2014, 9, e111559. [CrossRef]

29. Ipar, V.S.; Dsouza, A.; Devarajan, P.V. Enhancing Curcumin Oral Bioavailability Through Nanoformulations. Eur. J. Drug Metab. Pharm. 2019, 44, 459-480. [CrossRef]

30. Kushwaha, P.; Yadav, A.; Samim, M.; Flora, S.J.S. Combinatorial drug delivery strategy employing nano-curcumin and nano-MiADMSA for the treatment of arsenic intoxication in mouse. Chem. Biol. Interact. 2018, 286, 78-87. [CrossRef]

31. Yu, H.; Nguyen, M.H.; Cheow, W.S.; Hadinoto, K. A new bioavailability enhancement strategy of curcumin via self-assembly nano-complexation of curcumin and bovine serum albumin. Mater. Sci. Eng. C Mater. Biol. Appl. 2017, 75, 25-33. [CrossRef] [PubMed]

32. Dende, C.; Meena, J.; Nagarajan, P.; Nagaraj, V.A.; Panda, A.K.; Padmanaban, G. Nanocurcumin is superior to native curcumin in preventing degenerative changes in Experimental Cerebral Malaria. Sci. Rep. 2017, 7, 10062. [CrossRef] [PubMed]

33. Yan, J.; Wang, Y.; Zhang, X.; Liu, S.; Tian, C.; Wang, H. Targeted nanomedicine for prostate cancer therapy: Docetaxel and curcumin co-encapsulated lipid-polymer hybrid nanoparticles for the enhanced anti-tumor activity in vitro and in vivo. Drug Deliv. 2016, 23, 1757-1762. [CrossRef] [PubMed]

34. Kuttan, R.; Bhanumathy, P.; Nirmala, K.; George, M.C. Potential anticancer activity of turmeric (Curcuma longa). Cancer Lett. 1985, 29, 197-202. [CrossRef] 
35. Gupta, S.C.; Patchva, S.; Aggarwal, B.B. Therapeutic roles of curcumin: Lessons learned from clinical trials. Aa. J. 2013, 15, 195-218. [CrossRef] [PubMed]

36. Hewlings, S.J.; Kalman, D.S. Curcumin: A Review of Its' Effects on Human Health. Foods 2017, 6, 92. [CrossRef]

37. Miyazawa, T.; Nakagawa, K.; Kim, S.H.; Thomas, M.J.; Paul, L.; Zingg, J.-M.; Dolnikowski, G.G.; Roberts, S.B.; Kimura, F.; Miyazawa, T.; et al. Curcumin and piperine supplementation of obese mice under caloric restriction modulates body fat and interleukin-1 $\beta$. Nutr. Metab. 2018, 15, 12. [CrossRef]

38. Pufall, M.A. Glucocorticoids and Cancer. Adv. Exp. Med. Biol. 2015, 872, 315-333.

39. Miller, W.L.; Auchus, R.J. The molecular biology, biochemistry, and physiology of human steroidogenesis and its disorders. Endocr. Rev. 2011, 32, 81-151. [CrossRef]

40. Malikova, J.; Brixius-Anderko, S.; Udhane, S.S.; Parween, S.; Dick, B.; Bernhardt, R.; Pandey, A.V. CYP17A1 inhibitor abiraterone, an anti-prostate cancer drug, also inhibits the 21-hydroxylase activity of CYP21A2. J. Steroid Biochem. Mol. Biol. 2017, 74, 192-200. [CrossRef]

41. Udhane, S.S.; Dick, B.; Hu, Q.; Hartmann, R.W.; Pandey, A.V. Specificity of anti-prostate cancer CYP17A1 inhibitors on androgen biosynthesis. Biochem. Biophys. Res. Commun. 2016, 477, 1005-1010. [CrossRef] [PubMed]

42. Shozu, M.; Akasofu, K.; Harada, T.; Kubota, Y. A new cause of female pseudohermaphroditism: Placental aromatase deficiency. J. Clin. Endocrinol. Metab. 1991, 72, 560-566. [CrossRef] [PubMed]

43. Harada, N.; Ogawa, H.; Shozu, M.; Yamada, K.; Suhara, K.; Nishida, E.; Takagi, Y. Biochemical and molecular genetic analyses on placental aromatase (P-450AROM) deficiency. J. Biol. Chem. 1992, 267, 4781-4785. [PubMed]

44. Simpson, E.R. Aromatase cytochrome P450, the enzyme responsible for estrogen biosynthesis. Endocr. Rev. 1994, 15, 342-355.

45. Zanger, U.M.; Schwab, M. Cytochrome P450 enzymes in drug metabolism: Regulation of gene expression, enzyme activities, and impact of genetic variation. Pharm. Pher. 2013, 138, 103-141. [CrossRef] [PubMed]

46. Omura, T. Mitochondrial P450s. Chem. Biol. Interact. 2006, 163, 86-93. [CrossRef] [PubMed]

47. Pandey, A.V.; Flück, C.E. NADPH P450 oxidoreductase: Structure, function, and pathology of diseases. Pharm. Ther. 2013, 138, 229-254. [CrossRef] [PubMed]

48. Amalraj, A.; Pius, A.; Gopi, S.; Gopi, S. Biological activities of curcuminoids, other biomolecules from turmeric and their derivatives-A review. J. Tradit. Complement. Med. 2017, 7, 205-233. [CrossRef] [PubMed]

49. Majhi, A.; Rahman, G.M.; Panchal, S.; Das, J. Binding of curcumin and its long chain derivatives to the activator binding domain of novel protein kinase C. Bioorganic Med. Chem. 2010, 18, 1591-1598. [CrossRef]

50. Mondal, S.; Ghosh, S.; Moulik, S.P. Stability of curcumin in different solvent and solution media: UV-visible and steady-state fluorescence spectral study. J. Photochem. Photobiol. B Biol. 2016, 158, 212-218. [CrossRef]

51. Yoon, H.J.; Zhang, X.; Kang, M.G.; Kim, G.J.; Shin, S.Y.; Baek, S.H.; Lee, B.N.; Hong, S.J.; Kim, J.T.; Hong, K.; et al. Cytotoxicity Evaluation of Turmeric Extract Incorporated Oil-in-Water Nanoemulsion. Int. J. Mol. Sci. 2018, 19, 280. [CrossRef] [PubMed]

52. Chainani-Wu, N. Safety and anti-inflammatory activity of curcumin: A component of tumeric (Curcuma longa). J. Altern. Complementary Med. 2013, 9, 161-168. [CrossRef] [PubMed]

53. Gazdar, A.F.; Oie, H.K.; Shackleton, C.H.; Chen, T.R.; Triche, T.J.; Myers, C.E.; Chrousos, G.P.; Brennan, M.F.; Stein, C.A.; la Rocca, R.V. Establishment and characterization of a human adrenocortical carcinoma cell line that expresses multiple pathways of steroid biosynthesis. Cancer Res. 1990, 50, 5488-5496. [PubMed]

54. Wang, T.; Rainey, W.E. Human adrenocortical carcinoma cell lines. Mol. Cell. Endocrinol. 2012, 351, 58-65. [CrossRef] [PubMed]

55. Samandari, E.; Kempna, P.; Nuoffer, J.M.; Hofer, G.; Mullis, P.E.; Fluck, C.E. Human adrenal corticocarcinoma NCI-H295R cells produce more androgens than NCI-H295A cells and differ in 3beta-hydroxysteroid dehydrogenase type 2 and 17,20 lyase activities. J. Endocrinol. 2007, 195, 459-472. [CrossRef] [PubMed]

56. Pandey, A.V.; Miller, W.L. Regulation of 17, 20 lyase activity by cytochrome b5 and by serine phosphorylation of P450c17. J. Biol. Chem. 2005, 280, 13265-13271. [CrossRef] [PubMed]

57. Chung, B.C.; Matteson, K.J.; Voutilainen, R.; Mohandas, T.K.; Miller, W.L. Human cholesterol side-chain cleavage enzyme, P450scc: cDNA cloning, assignment of the gene to chromosome 15, and expression in the placenta. Proc. Natl. Acad. Sci. USA 1986, 83, 8962-8966. [CrossRef] 
58. Lindholm, J.; Juul, S.; Jorgensen, J.O.; Astrup, J.; Bjerre, P.; Feldt-Rasmussen, U.; Hagen, C.; Jorgensen, J.; Kosteljanetz, M.; Kristensen, L.; et al. Incidence and late prognosis of cushing's syndrome: A population-based study. J. Clin. Endocrinol. Metab. 2001, 86, 117-123. [CrossRef]

59. Dekkers, O.M.; Horváth-Puhó, E.; Jørgensen, J.O.L.; Cannegieter, S.C.; Ehrenstein, V.; Vandenbroucke, J.P.; Pereira, A.M.; Sørensen, H.T. Multisystem Morbidity and Mortality in Cushing's Syndrome: A Cohort Study. J. Clin. Endocrinol. Metab. 2013, 98, 2277-2284. [CrossRef]

60. Flück, C.E.; Tajima, T.; Pandey, A.V.; Arlt, W.; Okuhara, K.; Verge, C.F.; Jabs, E.W.; Mendonca, B.B.; Fujieda, K.; Miller, W.L. Mutant P450 oxidoreductase causes disordered steroidogenesis with and without Antley-Bixler syndrome. Nat. Genet. 2004, 36, 228-230. [CrossRef]

61. Carmina, E.; Rosato, F.; Jannì, A.; Rizzo, M.; Longo, R.A. Relative Prevalence of Different Androgen Excess Disorders in 950 Women Referred because of Clinical Hyperandrogenism. J. Clin. Endocrinol. Metab. 2006, 91, 2-6. [CrossRef] [PubMed]

62. Azziz, R.; Sanchez, L.A.; Knochenhauer, E.S.; Moran, C.; Lazenby, J.; Stephens, K.C.; Taylor, K.; Boots, L.R. Androgen Excess in Women: Experience with Over 1000 Consecutive Patients. J. Clin. Endocrinol. Metab. 2004, 89, 453-462. [CrossRef] [PubMed]

63. Chung, B.C.; Picado-Leonard, J.; Haniu, M.; Bienkowski, M.; Hall, P.F.; Shively, J.E.; Miller, W.L. Cytochrome P450c17 (steroid $17 \alpha$-hydroxylase/17,20 lyase): Cloning of human adrenal and testis cDNAs indicates the same gene is expressed in both tissues. Proc. Natl. Acad. Sci. USA 1987, 84, 407-411. [CrossRef] [PubMed]

64. Nakajin, S.; Shinoda, M.; Haniu, M.; Shively, J.E.; Hall, P.F. C21 steroid side chain cleavage enzyme from porcine adrenal microsomes. Purification and characterization of the 17 alpha-hydroxylase/C17,20-lyase cytochrome P-450. J. Biol. Chem. 1984, 259, 3971-3976. [PubMed]

65. Fernandez-Cancio, M.; Camats, N.; Fluck, C.E.; Zalewski, A.; Dick, B.; Frey, B.M.; Monne, R.; Toran, N.; Audi, L.; Pandey, A.V. Mechanism of the Dual Activities of Human CYP17A1 and Binding to Anti-Prostate Cancer Drug Abiraterone Revealed by a Novel V366M Mutation Causing 17, 20 Lyase Deficiency. Pharmaceuticals 2018, 11, 37. [CrossRef]

66. de Bono, J.S.; Logothetis, C.J.; Molina, A.; Fizazi, K.; North, S.; Chu, L.; Chi, K.N.; Jones, R.J.; Goodman, O.B.J.; Saad, F.; et al. Scher Abiraterone and Increased Survival in Metastatic Prostate Cancer. N. Eng. J. Med. 2011, 364, 1995-2005. [CrossRef] [PubMed]

67. Kim, S.B.; Cho, S.S.; Cho, H.J.; Yoon, I.S. Modulation of Hepatic Cytochrome P450 Enzymes by Curcumin and its Pharmacokinetic Consequences in Sprague-dawley Rats. Pharmacogn. Mag. 2015, 11, S580-S584.

68. Sasaki, T.; Sato, Y.; Kumagai, T.; Yoshinari, K.; Nagata, K. Effect of health foods on cytochrome P450-mediated drug metabolism. J. Pharm. Health Care Sci. 2017, 3, 14. [CrossRef]

69. Appiah-Opong, R.; Commandeur, J.N.; van Vugt-Lussenburg, B.; Vermeulen, N.P. Inhibition of human recombinant cytochrome P450s by curcumin and curcumin decomposition products. Toxicology 2007, 235, 83-91. [CrossRef]

70. Fleseriu, M.; Castinetti, F. Updates on the role of adrenal steroidogenesis inhibitors in Cushing's syndrome: A focus on novel therapies. Pituitary 2016, 19, 643-653. [CrossRef]

71. Montgomery, B.; Eisenberger, M.A.; Rettig, M.B.; Chu, F.; Pili, R.; Stephenson, J.J.; Vogelzang, N.J.; Koletsky, A.J.; Nordquist, L.T.; Edenfield, W.J.; et al. Androgen Receptor Modulation Optimized for Response (ARMOR) Phase I and II Studies: Galeterone for the Treatment of Castration-Resistant Prostate Cancer. Clin. Cancer Res. 2016, 22, 1356-1363. [CrossRef] [PubMed]

72. Fizazi, K.; Jones, R.; Oudard, S.; Efstathiou, E.; Saad, F.; Wit, R.d.; Bono, J.D.; Cruz, F.M.; Fountzilas, G.; Ulys, A.; et al. NMulticenter Trial Comparing Orteronel (TAK-700) Plus Prednisone With Placebo Plus Prednisone in Patients With Metastatic Castration-Resistant Prostate Cancer That Has Progressed During or After Docetaxel-Based Therapy: ELM-PC 5. J. Clin. Oncol. 2015, 33, 723-731. [CrossRef] [PubMed]

73. Kaku, T.; Hitaka, T.; Ojida, A.; Matsunaga, N.; Adachi, M.; Tanaka, T.; Hara, T.; Yamaoka, M.; Kusaka, M.; Okuda, T.; et al. Discovery of orteronel (TAK-700), a naphthylmethylimidazole derivative, as a highly selective 17,20-lyase inhibitor with potential utility in the treatment of prostate cancer. Bioorganic Med. Chem. 2011, 19, 6383-6399. [CrossRef] [PubMed]

74. Guan, Y.B.; Zhou, S.Y.; Zhang, Y.Q.; Wang, J.L.; Tian, Y.D.; Jia, Y.Y.; Sun, Y.J. Therapeutic effects of curcumin nanoemulsions on prostate cancer. J. Huazhong Univ. Sci. Technol. Med. Sci. 2017, 37, 371-378. [CrossRef] [PubMed] 
75. Wang, Y.-J.; Pan, M.-H.; Cheng, A.-L.; Lin, L.-I.; Ho, Y.-S.; Hsieh, C.-Y.; Lin, J.-K. Stability of curcumin in buffer solutions and characterization of its degradation product. J. Pharm. Biomed. Anal. 1997, 15, 1867-1876. [CrossRef]

76. Dahll, T.A.; Bilski, P.; Reszka, K.J.; Chignell, C.F. Photocytotoxicity of curcumin. Photochem. Photobiol. 1994, 59, 290-294. [CrossRef]

77. Yuan, R.; Zheng, F.; Zhong, S.; Tao, X.; Zhang, Y.; Gao, F.; Yao, F.; Chen, J.; Chen, Y.; Shi, G. Self-Assembled Nanoparticles of Glycyrrhetic Acid-Modified Pullulan as a Novel Carrier of Curcumin. Molecules 2014, 19, 13305-13318. [CrossRef] [PubMed]

78. Shoba, G.; Joy, D.; Joseph, T.; Majeed, M.; Rajendran, R.; Srinivas, P.S. Influence of piperine on the pharmacokinetics of curcumin in animals and human volunteers. Planta Med. 1998, 64, 353-356. [CrossRef] [PubMed]

79. Delecroix, B.; Abaidia, A.E.; Leduc, C.; Dawson, B.; Dupont, G. Curcumin and Piperine Supplementation and Recovery Following Exercise Induced Muscle Damage: A Randomized Controlled Trial. J. Sports Sci. Med. 2017, 16, 147-153.

80. Srivilai, J.; Rabgay, K.; Khorana, N.; Waranuch, N.; Nuengchamnong, N.; Wisuitiprot, W.; Chuprajob, T.; Changtam, C.; Suksamrarn, A.; Chavasiri, W.; et al. Anti-androgenic curcumin analogues as steroid 5-alpha reductase inhibitors. Med. Chem. Res. 2017, 26, 1550-1556. [CrossRef]

81. Changtam, C.; de Koning, H.P.; Ibrahim, H.; Sajid, M.S.; Gould, M.K.; Suksamrarn, A. Curcuminoid analogs with potent activity against Trypanosoma and Leishmania species. Eur. J. Med. Chem. 2010, 45, 941-956. [CrossRef] [PubMed]

82. Parohan, M.; Sarraf, P.; Javanbakht, M.H.; Foroushani, A.R.; Ranji-Burachaloo, S.; Djalali, M. The synergistic effects of nano-curcumin and coenzyme Q10 supplementation in migraine prophylaxis: A randomized, placebo-controlled, double-blind trial. Nutr. Neurosci. 2019, 26, 1-10. [CrossRef] [PubMed]

83. Jazayeri-Tehrani, S.A.; Rezayat, S.M.; Mansouri, S.; Qorbani, M.; Alavian, S.M.; Daneshi-Maskooni, M.; Hosseinzadeh-Attar, M.J. Nano-curcumin improves glucose indices, lipids, inflammation, and Nesfatin in overweight and obese patients with non-alcoholic fatty liver disease (NAFLD): A double-blind randomized placebo-controlled clinical trial. Nutr. Metab. (Lond.) 2019, 16, 8. [CrossRef] [PubMed]

84. Asadi, S.; Gholami, M.S.; Siassi, F.; Qorbani, M.; Khamoshian, K.; Sotoudeh, G. Nano curcumin supplementation reduced the severity of diabetic sensorimotor polyneuropathy in patients with type 2 diabetes mellitus: A randomized double-blind placebo-controlled clinical trial. Complement Ther. Med. 2019, 43, 253-260. [CrossRef] [PubMed]

85. Corson, T.W.; Crews, C.M. Molecular understanding and modern application of traditional medicines: Triumphs and trials. Cell 2007, 130, 769-774. [CrossRef] [PubMed]

86. Kohler, P.O.; Bridson, W.E. Isolation of Hormone-Producing Clonal Lines of Human Choriocarcinoma1. J. Clin. Endocrinol. Metabol. 1971, 32, 683-687. [CrossRef] [PubMed]

87. Bird, I.M.; Hanley, N.A.; Word, R.A.; Mathis, J.M.; McCarthy, J.L.; Mason, J.I.; Rainey, W.E. Human NCI-H295 adrenocortical carcinoma cells: A model for angiotensin-II-responsive aldosterone secretion. Endocrinology 1993, 133, 1555-1561. [CrossRef]

88. Rainey, W.E.; Bird, I.M.; Mason, J.I. The NCI-H295 cell line: A pluripotent model for human adrenocortical studies. Mol. Cell. Endocrinol. 1994, 100, 45-50. [CrossRef]

89. Udhane, S.S.; Pandey, A.V.; Hofer, G.; Mullis, P.E.; Flück, C.E. Retinoic acid receptor beta and angiopoietin-like protein 1 are involved in the regulation of human androgen biosynthesis. Sci. Rep. 2015, 5, 10132. [CrossRef]

90. Pandey, A.V.; Mellon, S.H.; Miller, W.L. Protein phosphatase 2A and phosphoprotein SET regulate androgen production by P450c17. J. Biol. Chem. 2003, 278, 2837-2844. [CrossRef]

91. Shaw, G.; Morse, S.; Ararat, M.; Graham, F.L. Preferential transformation of human neuronal cells by human adenoviruses and the origin of HEK 293 cells. FASEB J. 2002, 16, 869-871. [CrossRef] [PubMed]

92. Phattanawasin, P.; Sotanaphun, U.; Sriphong, L. Validated TLC-Image Analysis Method for Simultaneous Quantification of Curcuminoids in Curcuma longa. Chromatographia 2009, 69, 397-400. [CrossRef]

93. Lephart, E.D.; Simpson, E.R. Assay of aromatase activity. Methods Enzymol. 1991, 206, 477-483. [PubMed]

94. Pandey, A.V.; Kempna, P.; Hofer, G.; Mullis, P.E.; Flück, C.E. Modulation of human CYP19A1 activity by mutant NADPH P450 oxidoreductase. Mol. Endocrinol. 2007, 21, 2579-2595. [CrossRef] [PubMed]

95. Krieger, E.; Darden, T.; Nabuurs, S.B.; Finkelstein, A.; Vriend, G. Making optimal use of empirical energy functions: Force-field parameterization in crystal space. Proteins 2004, 57, 678-683. [CrossRef] [PubMed] 
96. DeVore, N.M.; Scott, E.E. Structures of cytochrome P450 17A1 with prostate cancer drugs abiraterone and TOK-001. Nature 2012, 482, 116-119. [CrossRef] [PubMed]

97. Ghosh, D.; Griswold, J.; Erman, M.; Pangborn, W. Structural basis for androgen specificity and oestrogen synthesis in human aromatase. Nature 2009, 457, 219-223. [CrossRef]

98. Pallan, P.S.; Wang, C.; Lei, L.; Yoshimoto, F.K.; Auchus, R.J.; Waterman, M.R.; Guengerich, F.P.; Egli, M. Human Cytochrome P450 21A2, the Major Steroid 21-Hydroxylase: Structure of the enzyme-progesterone substrate complex and rate-limiting c-h bond cleavage. J. Biol. Chem. 2015, 290, 13128-13143. [CrossRef]

99. Trott, O.; Olson, A.J. AutoDock Vina: Improving the speed and accuracy of docking with a new scoring function, efficient optimization, and multithreading. J. Comput. Chem. 2010, 31, 455-461. [CrossRef]

100. Wang, Y.; Luo, J.; Li, S.Y. Nano-Curcumin Simultaneously Protects the Blood-Brain Barrier and Reduces M1 Microglial Activation During Cerebral Ischemia-Reperfusion Injury. ACS Appl. Mater. Interfaces 2019, 11, 3763-3770. [CrossRef]

101. Jaguezeski, A.M.; Souza, C.F.; Perin, G.; Reis, J.H.; Gomes, T.M.A.; Baldissera, M.D.; Vaucher, R.A.; de Andrade, C.M.; Stefani, L.M.; Gundel, S.S.; et al. Effect of free and nano-encapsulated curcumin on treatment and energetic metabolism of gerbils infected by Listeria monocytogenes. Microb. Pathog. 2019, 134, 103564. [CrossRef] [PubMed]

(C) 2019 by the authors. Licensee MDPI, Basel, Switzerland. This article is an open access article distributed under the terms and conditions of the Creative Commons Attribution (CC BY) license (http://creativecommons.org/licenses/by/4.0/). 